\title{
Working
}

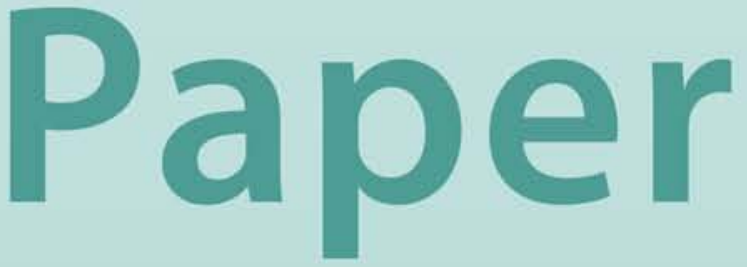




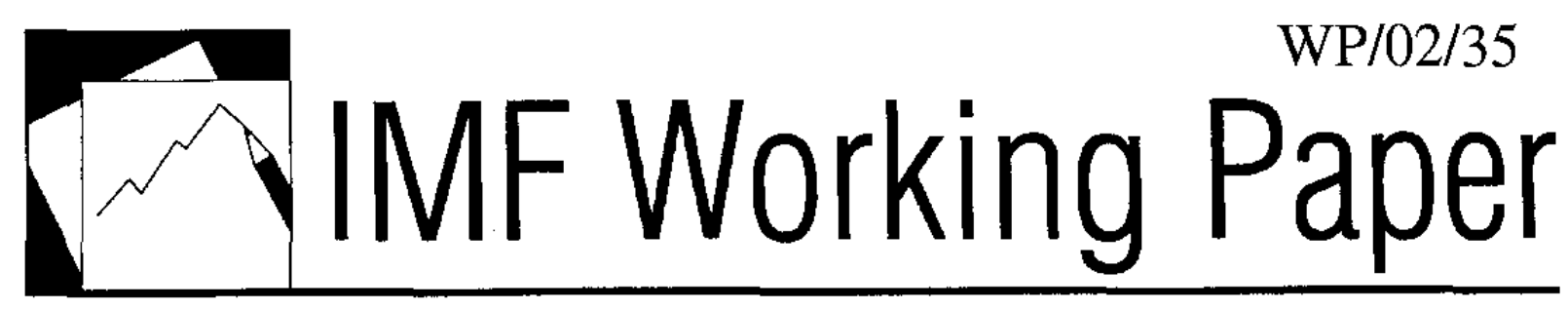

Social Sector Spending in a Panel of Countries

\author{
Reza Baqir
}




\title{
IMF Working Paper
}

\section{Research Department \\ Social Sector Spending in a Panel of Countries}

\author{
Prepared by Reza Baqir ${ }^{1}$
}

Authorized for distribution by Eduardo Borensztein

February 2002

\begin{abstract}
The views expressed in this Working Paper are those of the author(s) and do not necessarily represent those of the IMF or IMF policy. Working Papers describe research in progress by the author(s) and are published to elicit comments and to further debate.
\end{abstract}

This paper presents evidence on the political and economic determinants of social sector spending from a panel dataset. The principal finding is that democratization in countries, as measured by within-country variation in subjective indices of democracy, is a significant predictor of government spending on education and health. The relationship is robust to controlling for a variety of factors and the estimated magnitudes suggest that an increase from the lowest to the highest rating for democracy for a country is associated with approximately 1 percent more central government spending and 3 percent more general government spending in social sectors, as a percent of GDP.

JEL Classification Numbers:D72, H40, H50, O23

Keywords: government spending, social sectors, democracy

Author's E-Mail Address: $\quad$ rbaqir@imf.org

\footnotetext{
${ }^{1}$ I am grateful to Aasim Husain, Xavier Sala-i-Martin, Paolo Mauro, Gian Maria Milesi-Ferretti, Jeronimo Zettelmeyer, and participants in the Research Department Seminar at the IMF and the public economics workshop at Duke University for helpful comments. The views expressed are solely those of the author and not necessarily those of the affiliated institution.
} 


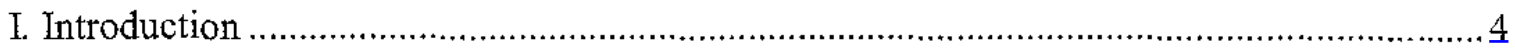

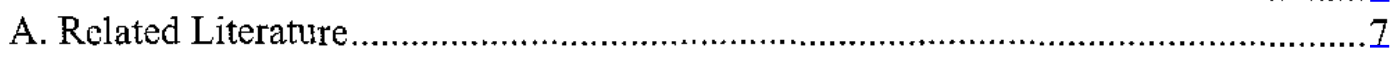

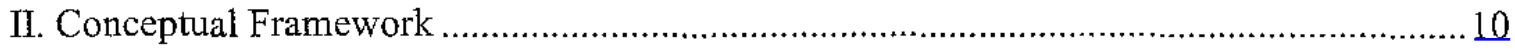

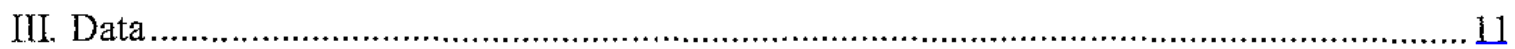

A. Government spending data................................................................... 11

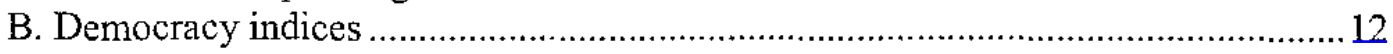

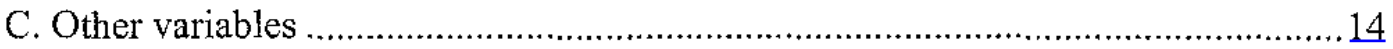

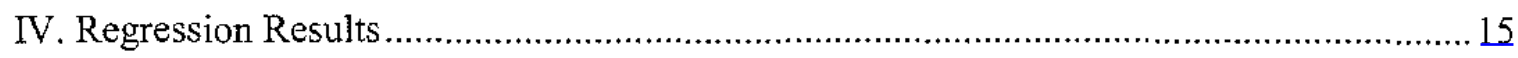

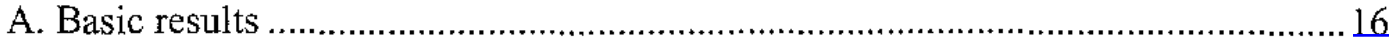

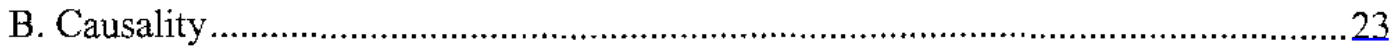

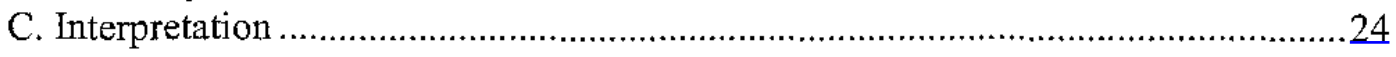

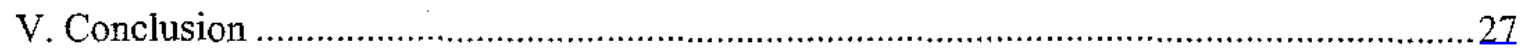

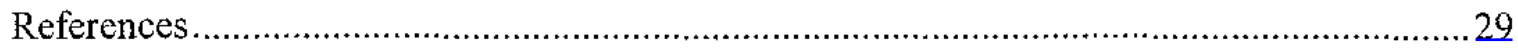

Figures

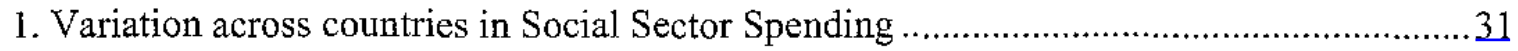

2. Within-county variation in Social Sector Spending, 1985-98 ….................................32

3. Gross Primary Enrollment Rates, by decile of Education Spending ...............................33

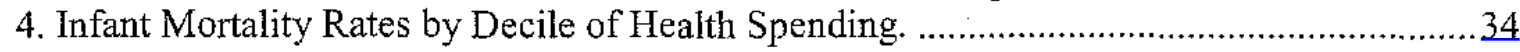

5. Correlation between Alternative Measures of Democracy ..........................................35

6. Partial Scatter of Education Spending and Democracy ..................................................

Tables

1. Summary Statistics for Government Spending Variables .............................................37

2. Summary Statistics for Democracy Indices from Freedom House and Polity IV .............. 38

3. Transition probabilities (in \%) for PIV Institutionalized Democracy Score ......................38

4. Changes in Social Sector Spending by Episodes of Changes in Democracy Index ............39

5. Regressions for Total Government Spending ............................................................

6. Regressions for Education and Health Spending, Between Estimator .............................41

7. Regressions for Education and Health Spending, Fixed Effects .................................. 42

8. Regressions for Education and Health Spending, Fixed Effects using Central Government FAD data......................................................................................4

9. Sensitivity of Estimated Coefficients on Democracy and Government Spending

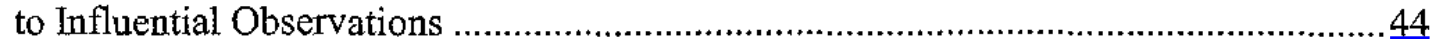

10. Regressions for Social Sector Spending, Freedom House Measures of Democracy.........45 
11. Regressions for Social Sector Spending, Period Averages and Allowing for Correlation within Countries ..........................................................................46

12. IV Estimation for Social Sector Spending ………...............................................4

13. First Differences Estimation for Social Sector Spending ............................................48

14. Rclationship between Democracy and Decentralization Indices...................................49

15. Between Regressions for General Government Expenditure on Social Sectors................50

Appendix Tables

1. Episodes of Change in Polity IV Index of Democracy .....................................................51

2. Sources and Summary Statistics for Control Variables ................................................52 


\section{INTRODUCTION}

Countries at similar levels of economic development vary considerably in how much their governments spend on social sectors--education and health. For a sample of 100 countries for which consistent data are available on central government spending, Figure 1 shows the variation in social sector spending by decile of real GDP per capita averaged for each country for the period 1985-98. At each decile of income there is substantial variation among the countries in how much their central governments devote to social sectorsmaximum spending is several times the minimum spending for each decile. For instance, in the fifth decile, the total of education and bealth spending varies from 2.9 percent of GDP for Dominican Republic to 12.9 percent of GDP for Namibia. Social sector spending also changes considerably within countries over time. For the same sample of countries, Figure 2 shows the range of social sector spending for each country over available observations for the period 1985-98. The figure shows that a quarter of the countries witnessed a change in social spending of 2.8 percent or more over the period and half of the 100 countries in the sample saw a change of 1.85 percent or more. Given average social spending in a country of 6.5 percent (and cross-sectional standard deviation of 3.0 percent of country means) these are non-trivial changes in social spending within countries over time.

Given this significant variation in social sector spending across and within countries, a natural, and important, question which arises is what factors help to explain this variation in social sector spending across and within countries. There is surprisingly little formal theoretical work in economics looking at the determinants of allocation of government resources to education and health sectors. Recent literature in the area of political economics (Persson and Tabellini (2000a)) has looked at the determination of the size and composition of spending, but typically the composition examined is that between pure transfer spending and general government consumption, and not the allocation to social sectors versus others. ${ }^{2}$ Spending on social sectors is important because it tends to benefit the poor relatively more than the rich and because, arguably, it increases the human capital of the economy, which can produce direct growth effects and indirect spillover benefits for the rest of the economy. While little formal work exists on examining the determinants of government spending in these sectors, one widely held view is that greater democratization, by leading to greater participation of the poor in the political process, leads to outcomes which benefit the poor, with one such outcome being the amount of public resources devoted to provision of education and health services. For example, the 2000/2001 World Development Report of the World Bank states "[the] state will deliver more effectively to ... poor people in particular if ... political regimes honor the rule of law, allow the expression of political voice, and encourage the participation of poor people in the political process" (World Bank (2000), p. 99). ${ }^{3}$ More specifically, the recent literature on democracy and growth (Barro (1996), Wacziarg and Tavares (2000), Wacziarg (2001), and others) also turns on a similar argument

\footnotetext{
${ }^{2}$ The term "social sectors" refers to education and health sectors throughout the paper, unless otherwise stated.

${ }^{3}$ Also see the background papers to the World Development Report 2000/2001. Moore and Putzel (1999) synthesize the background research on politics and poverty.
} 
for one of the channels through which democracy affects growth. In a majority-vote setting, greater democracy in a country is taken to be associated with a movement of the pivotal voter from being located in the upper tail of the distribution towards the median. Through a standard Meltzer and Richard (1981) type effect, this leads to greater spending on education, which has a positive growth effect due to human capital externalities. There is, however, very little comprehensive international evidence on whether greater democratization leads to greater education and health spending.

The purpose of this paper is to examine the determinants of social sector spending for a large panel of countries. One reason for the dearth of cross-country work is the unavailability of comprehensive and consistent data on government spending in these sectors. Using a new dataset on government spending compiled at the TMF which arguably provides better measures of social sector spending for a panel of over 100 countries for the period 1985-98, and paying explicit attention to cross-sectional versus within-country variation, this paper presents systematic evidence on the relationship between social sector spending and economic and political factors.

The primary finding is that democratization, as measured by subjective indices of democracy, is significantly and positively associated with the within-country variation in social sector spending, but not with the pure cross-sectional variation in the full sample of countries. Identifying effects of democratization on social sector spending in the cross section of countries is problematic because of the presence of time-invariant country-specific factors which are potentially correlated with the determinants of social sector spending. When such factors arc controlled for using a fixed effects specification, a positive and significant relationship emerges between measures of democracy and government spending on social sectors. This relationship holds after controlling for per capita real GDP, total government spending as a share of GDP, population size, openness, age-structure, and interestingly, share of military spending in total GDP. The last factor implies that the traditional argument given by developing countries in their defense of low social sector spending - that they are constrained by security considerations to prioritize defensc spending-does not present a constraint for the beneficial effects of democratization on social sector spending. The estimated relationship is also robust to consideration of a variety of factors: (i) it becomes stronger when the spending data are made more consistent by using a common source and common level of government coverage, (ii) the relationship persists when five year country averages are used instead of yearly data to address business cycle effects, and (iii) timing of the changes in social sector spending and democracy indices and instrumental variables estimation suggest that causation runs from democratization to social sector spending. The estimated magnitude of effect indicates that a one standard deviation increase in the index of democracy is associated with a 0.09 standard deviation increase in social sector spending as a share GDP, and a 0.16 standard deviation increase as a share of total government spending. ${ }^{4}$ In terms of levels of the variables, a change from the lowest

\footnotetext{
${ }^{4}$ Standard deviations refer to the within country variation as these are the estimates from the fixed effects model.
} 
value on the democracy index to the highest is associated with somewhere between a 0.7 percent to 1.5 percent increase in central government social sector spending (as share of GDP). ${ }^{5}$ Estimates for general (central plus sub-national) government spending suggest that such a change in democratization leads to 3 percent more of GDP being devoted to social sectors.

The empirical results also show that social sector spending reacts less than one-to-one to changes in total spending. Fiscal contractions are associated with less-than-proportionate reductions in social sector spending. I do not find statistically significant evidence that social sector spending is more sensitive to total spending in times of fiscal contractions than in fiscal expansions. This evidence should contribute usefully to the existing debate on the effects of adjustment lending programs on pro-poor government spending and corroborates the findings in Mauro (2000).

The paper is organized as follows. The rest of this section discusses existing theoretical and empirical work related to the results in this paper. The next section advances two conceptual frameworks to consider the effects of democratization on social sector spending. One framework builds on a median-voter setting, as in the literature on democracy and growth, and the other on representative democracy where the population is composed of different groups, defined along some other dimension (such as ethnicity or region) with each group having a proportion of poor within its composition which would benefit relatively more from social sector spending. The third section describes the data used in the paper and, in particular, discusses sources and construction of the government spending data and the democracy indices. This section also examines the relationship between two widely used measures of democracy, the Freedom House/Gastil measure of "political rights" and the Polity IV "institutionalized democracy" score, and argues that, due to methodological changes which have been made periodically in the Freedom House measures, they may be more apt for comparing democracy across countries for any given year rather than for comparing changes in democracy within countries over time. Details on the sources and construction of the other variables are provided in the data appendix. Section IV presents the results from panel regressions. It is composed of three sub-parts. First, it presents the basic results with respect to (a) total government spending and (b) social sector spending, providing both the pure cross-sectional estimates and then results from fixed effects. It then discusses several exercises undertaken to examine the robustness of the result with respect to democratization. Second, section IV presents evidence from instrumental variables estimation and from differences-on-lagged-differences regressions to discuss whether the partial correlations can be interpreted causally. Third, it advances an interpretation which reconciles the apparent disparity between the pure cross-sectional and within-country results,

\footnotetext{
${ }^{5}$ These estimates are taken from Table 9 and Table and the related discussion in section IV.

${ }^{6}$ Mauro (2000) reports that of the 60 (non-overlapping) country instances in the period 1985-98 in which total government spending fell by more than 5 percentage points, the share of education and health spending in total spending rose in three-quarters of the cases over the three year period. See Cashin et. al. (2001).
} 
focusing on the relationship between decentralization and democracy. Section V concludes with a summary of the principal findings and a discussion of ideas for further research.

\section{A. Related Literature}

This paper is related to three strands of literature. First, and by way of motivation, is the empirical work on the relationship between social sector spending and social sector outcomes, such as measures of school enrollment and life expectancy. It is important to note that this paper does not address this relationship-the focus here is on the direct political economy channel between democratization and spending in social sectors. The papers in this area discuss the effects of such spending, whether caused by democratization or other reasons. ${ }^{7}$ The consensus view seems to be that a lot depends on the targeting of government expenditures within these sectors. In particular, government expenditures on primary education and basic health seem to do the most for the education and health outcomes of the poor, and poverty in general. Cross-country data on the allocation of spending within the education and health sectors are however not available for a large number of countries for a large number of years that they could be usefully brought into the analysis in this paper. Thus, in the absence of these data, if intra-sectoral spending shares do not change as total spending in the sector rises, then an increase in overall spending in the sector can be taken to be associated with greater spending in the sub-components which benefit the poor the most. For the countries and years in the sample used in this study, Figure 3 and Figure 4 show the relationship between deciles of spending in education and health respectively, and the outcomes in these sectors for the pooled sample of observations. These graphs are only indicative of a general relationship, suggesting that spending on these sectors is associated with positive outcomes for the poor. Even if one believes that government spending in these sectors has no relationship with the education and health outcomes for the poor, it is still, and perhaps even more, interesting to ask why, then, do governments devote significant portions of their budgets to these sectors and what explains the changes in these allocations.

The second strand of literature is theoretical work on the determinants of education and/or health spending. As mentioned above one context in which social sector spending can be considered is the Meltzer and Richard (1981) framework in which people in the lower tail of the distribution demand greater public services financed out of a proportional tax on income. A decrease in the income of the pivotal voter (arising either from a increase in the skewness of the income distribution or from increased participation by greater numbers from the lower tail of the distribution) raises government spending since it carries a redistributive component. Saint-Paul and Verdier (1993) and Wacziarg (2001) consider this effect in two different settings. Saint-Paul and Verdier (1993) present a model where public education constitutes an instrument of intra-generational redistribution and also creates human capital which promotes long-run growth by raising the human capital of successive generations. In their set-up, democratization raises spending on public education and increases both growth

\footnotetext{
${ }^{7}$ For a comprehensive review see World Bank (2000). See also Gupta et. al (1999) for some recent evidence using same government spending data as in this paper, relating spending to outcomes.
} 
and equalization of income. Wacziarg (2001) considers a human-capital augmented Solow model where saving in human capital is a public choice modeled in a median-voter setting. Each agent seeks to maximize steady-state level of consumption and a voter's ideal saving rate depends in part on the voter's relative position in the income distribution profile. A decrease in decisive agent's income relative to mean (as in the case of greater democracy) is associated with two counter-veiling effects on the level of ideal saving rate in human capital. On the one, hand a poorer agent would want greater human capital as it represents greater redistribution and the voter gets a bigger share of the pie but, on the other, greater redistribution distorts the economy which affects the steady state level of income and hence may reduce the size of the pie. In Wacziarg's model, which effect dominates depends on the saving rate in physical capital relative to population growth. When saving in physical capital is high relative to population growth, greater democracy tends to increase human capital accumulation. Wacziarg (2001) presents empirical evidence consistent with these predictions, relating the Barro-Lee measures of human capital and school enrollment rates to measures of democracy, amongst other factors. In terms of relevance for this paper it should be noted that despite the public choice channel assumed in the model the empirical work focuses on the determinants of school enrollment and not explicitly the share of public resources devoted to education. ${ }^{8}$

The third strand of related literature is existing empirical work on the determinants of the levels of, and changes in, social spending. There are two related sets of papers in this area: those which look at other determinants of social sector spending and those which explicitly focus on the effect of democratization. In the former group, Mauro (1998) looks at education spending in a cross-section of countries and relates it to indices of corruption of the government, the overall idea being that corrupt politicians are likely to favor spending in other areas such as infrastructure, in which big projects mean bigger side payments and commissions. He finds a significant and negative effect of corruption on the share of education expenditure in total income. Ravallion (2000) looks at whether fiscal consolidation in Argentina in the 1980 s and 90 s led to more than proportionate cuts in social spending. He differentiates between social services (education, health, water and sewerage, housing and urban development, and labor programs) and social insurance (pensions, public health insurance, unemployment insurance) and argues that spending on social services is pro-poor (in that the poorest $x$ percent of households receive more than $x$ percent of spending) but that this is not so for social insurance. He finds that increases in the total spending are not statistically significantly associated with increases in total social spending but that cuts in total spending produce statistically significant reductions in total social spending with an elasticity greater than unity. Moreover, he finds that the elasticity to budget cuts is very similar for social services as for social insurance, indicating that the more pro-poor social spending does not suffer more than other social spending.

\footnotetext{
${ }^{8}$ At one stage Wacziarg (2001) provides results for government expenditure on education expressed as a share of GDP but does not get significant results for the effect of democracy on education expenditures. It should be noted that these are pure cross-sectional results.
} 
Papers focusing on the relationship between democratization and social spending include Lindert $(1994,1996)$, Husted and Kenny (1997), and Snyder and Yackovlev (2000). Lindert (1994) examines social transfers in a sample of 21 countries for the period 1880 1930 and relates it to, amongst other factors, three democracy-related variables: a 0-1 indicator for democracy constructed from Banks (1971); a indicator for whether a majority of the women were enfranchised in the previous election; and voter turnout rate, defined as the ratio of voters to population over the age of 20 in the enfranchised genders in the last election. He finds significant effects of all three variables although, interestingly, the effect of the coded democracy variable is negative while the estimated effects for the other two variables is positive, with the net effect depending heavily on the share of franchised-gender adults who voted. Lindert's measure of social transfers includes pure redistributive transfer spending (such as welfare and unemployment compensation) as well as expenditure on housing and health. When one looks only at the results for health spending (the closest comparison to the results in this paper) one finds significant effects of the democracy indicator and voter turnout, with negative and positive effects respectively, with the net effect depending heavily on the share of franchised adults. ${ }^{2}$ Lindert (1996) conducts a similar exercise for 19 countries for the period 1960-1981 using data from an OECD study. Once again he finds important effects of voter turnout (as increasing social spending) but looking at education and health spending separately the effect is only significant for education spending. Overall, both studies point to an important role for variables capturing political participation in affecting total social spending, although the effects become somewhat fragile when he looks specifically at education and health spending. ${ }^{10}$ Husted and Kenny (1997) look at the effects of the expansion of the voting franchise in the United States on state expenditures for the period 1950-98. They find strong support for the hypothesis that welfare spending rises as the decisive voter moves down the income distribution. Note again that they do not focus on education and health expenditures but transfer payments. Snyder and Yackovlev (2000) present evidence from a panel of 19 Latin American and Caribbean countries for the period 1970-96. They disaggregate social spending into education and health and other components and explain changes in spending as functions of the level of political and program specific variables. Using a binary indicator for democratic regimes they find that social spending (particularly education and health) grows more under democratic rule. Unlike this paper which focuses on the level-level relationship they focus on growth rates of spending under different regimes. They also find that more pro-poor components of social spending (which they take to be primary and secondary education spending) are relatively more insulated from economic shocks.

Compared to this literature the value-added of this paper is on three fronts. First, it undertakes a comprehensive cross-county panel study instead of focusing on one region or a few countries, using a data set on government spending which is arguably of better quality

\footnotetext{
${ }^{9}$ The voter turnout variable however is not significant when Lindert (1994) reports results from a fixed-effects model.

${ }^{10}$ Lindert's measure of social spending lumps together education and health spending with transfer payments and other redistributive type spending.
} 
than existing measures taken from Government Financial Statistics. Second, it focuses explicitly on spending in two sectors, education and health. The defining characteristics of spending in these two sectors, as opposed to transfers, are that (i) such spending is considered to be more pro-poor (Ravallion (2000)) and (ii) it is likely to have positive spillovers. And third, the empirical work in this paper focuses explicitly on distinguishing between the pure cross-sectional and within-country variation.

\section{CONCEPTUAL FRAMEWORK}

As discussed above, an often used conceptual framework under which the effects of democratization on government spending are considered is the median voter framework of Meltzer and Richard (1981). This is usually done in a setting where tax revenues go to finance one type of government service. This one type of government expenditure benefits everybody but, because of the redistribution inherent in the taxation scheme, the poor demand more of it. To apply the same sort of argument to the allocation of government expenditures between social and other sectors it is useful to think of the government's decision in two stages: first it decides the size of the budget and second, its allocation between two types of spending: social and all other. Agents benefit from consuming both types of public expenditures and a private good, expenditure on which equals the disposable income. Under such a framework the standard Meltzer-Richard argument applies to the size of the budget-as the pivotal voter moves down the income distribution ladder the equilibrium size of the government budget rises. However, if there is no correlation between an agent's income and his/her relative preference for one type of spending versus the other, such a movement of the pivotal voter would have no effect on the composition of government spending. To get greater shares of government spending devoted to social sectors as the median voter becomes poorer one needs the assumption that poorer agents derive more direct utility from the social-sector good (education, health) than the rich. This is a plausible assumption and can be justified on several grounds. In particular, credit constraints, fixed costs, and coordination problems can prevent the poor from being able to finance investment in human capital.

Effects of democracy on social sector spending can arise in a different, non-median voter framework as well. Consider a model of government in the spirit of legislative bargaining (Persson and Tabellini (2000b), Milesi-Ferretti et. al. (2001)). The population of a country is stratified into $J$ groups based on some characteristic of agents other than income (e.g. ethnicity). There is a proportion of poor in each group. An increase in democracy in such a framework can be taken to mean that a greater number of groups, through their elected representatives, get to participate in the legislative bargaining process. This stylization applies readily to cases where a military government, enjoying the tacit support of one or two ethnic groups in the population is succeeded by national elections which give representation to a greater number of groups in the legislature. A key feature of social spending is that it can be targeted by group. If groups are geographically concentrated, as is often the case in countries, this follows readily since such spending on education and health has a strong local public good flavor. If the groups are not geographically concentrated, social spending can still be targeted by group. For instance if the dimension of segregation is language, the choice 
of the language of instruction can effectively preclude members of other groups from consuming the good. Non-social spending, such as defense and general administration may not be as easily targeted. Defense is a pure national good, while transfer spending in the form of entitlement programs depend on individual's income and employment characteristics and would go to members of each group. Given this correspondence between social and nonsocial spending and targetable and non-targetable spending, a standard result in models where group members elect representatives is that voters in each group, anticipating the conflict in the legislature on the group-specific type of spending select candidates which are more aggressive in their preferences for social spending (than the group median). An increase in democracy, associated with participation from more group representatives in the legislature, can then readily lead to tilting spending towards social sectors.

Whether one believes the median voter story or the legislative bargaining story, it is straightforward to see that an increase in democracy is expected to lead to greater socialsector spending as a share of total spending, and as a share of total resources of the economy. "The primary contribution of the paper is empirical: to take these and related predictions to the data.

\section{DATA}

One of the constraints in undertaking cross-country empirical work to identify the determinants of social sector spending is the availability of consistent and good quality government spending data. I discuss in this section (i) the sources of the spending data; (ii) the measures of democracy used; and (iii) description of other variables used in the study controls.

\section{A. Government spending data}

Data on total government spending and spending in education and health are taken from a dataset compiled by the Fiscal Affairs Department of the IMF (FAD). ${ }^{12}$ One of the primary motivations for putting these data together was the limitation in the data available from existing sources, such as the Government Financial Statistics database (GFS). The data on government spending and sectoral allocations are originally taken from IMF country documents produced in association with IMF's program activities in each country. These data are then sent to the desk economist for each country for verification and reconciliation. Two nice features of this database are the following. First, the compilation process pays specific attention to planned versus actual expenditures in education and health sectors. Thus the spending data are revised when subsequent year's documents become available for a country and reveal the actual expenditures. Second, the data note whether the spending measures refer to central, general, or some other level of government activity. In addition I

\footnotetext{
${ }^{11}$ Testing alternative theories which predict a positive reduced-form partial correlation between democracy and social sector spending is left for future research.

12 These data are described in Gupta et. al. (2000).
} 
also supplement with data from the GFS (consolidated central government level) for countries not covered by the FAD data. ${ }^{13}$ In general, the FAD data cover mostly developing countries and exclude the OECD countries. The distinction between central and general spending is important for two reasons. First, since countries vary in whether the data for them refer to central or general, the cross-sectional variation is contaminated with effects stemming only from the level of government activity. This is one important reason for doing fixed effects, assuming that the level of coverage over time does not change for a country, as is the case for these data. Second, it allows one to look separately at countries by the level of government activity covered to make more consistent cross-country comparisons. The biggest strength of the dataset is simply the much larger number of countries and years and for which the data are available. The data set covers 167 countries for the period 1985-98. Actual coverage is smaller, as expected. Total government spending data, as a percent of GDP, is available for 1870 country-years (or 80 percent of the total number of cells in the panel of $2338=167 \times 14$ ) and education and heath spending data are available for 1415 country-years (or 60 percent of the total number of cells in the panel). Table 1 gives the summary statistics on each of these measures of government spending, breaking down the data between cross-sectional and within country variation, and shows that there are on average between 9.8 and 11.4 observations available per country for the 14 year period. The outliers in the ratio of total spending to GDP are small countries: the countries with government spending greater than 80 percent of GDP are: Kiribati, Marshall Islands, Sao Tome and Principe, and West Bank and Gaza. The overall mean of social sector spending is 6.5 percent as share of GDP and 20.1 percent as share of total government expenditures.

\section{B. Democracy indices}

Two indices used in the empirical literature are the Freedom House/Gastil (FH) measures of political rights and the "institutionalized democracy" score from the Polity IV dataset (PIV), originally due to Gurr and associates. ${ }^{14}$ The former source is an exercise conducted each year by analysts working for the Freedom House who give each country a score of political rights between 1 and 7 with 1 representing the highest rating for political rights. These scores are based on a several-question checklist. Two principle areas covered by the checklist are whether there are free and fair elections with no restrictions on political competition and whether there are constraints on the executive's authority. The Polity IV measure of institutionalized democracy is on a $0-10$ scale with 10 representing the highest rating for democracy. Unlike the Freedorn House measures for which new scores are published each successive year, the PIV scores come from a data set which is updated every few years with a comprehensive effort at re-visiting the country developments for each country over the period covered. If the methodology for computing the democracy score changes, the effort includes revising the democracy scores for previous years to make them

\footnotetext{
${ }^{13}$ A country in the dataset either gets all its data from the FAD dataset or, if not available, from the GFS. I do not mix the time series data for any given country from the two sources.

${ }^{14}$ See the first four chapters in Inkeles (1991) for a description of these alternative indices.
} 
consistent with the current methodology used-that is, to make the time series consistent. The factors upon which countries get institutionalized democracy score are very similar to those mentioned in Freedom House scores. And indeed there is a very high correlation between the two measures. Figure 5 shows the relationship between country averages for the two democracy indices where both have been converted to a $0-1$ scale with 1 representing the highest rating for democracy. The figure uses all available observations for FH and PIV and there are at least 6 observations per country (average number of observations per country for the 14 year period is 12.6) with a total of 142 countries. Aside from the very low value of the PIV democracy score where there is some dispersion in the FH measure, the figure shows a very smooth relationship between the two measures. The correlation coefficient is 0.96 and is highly significant. The two measures are also quite highly correlated in first-differences, with a correlation coefficient of 0.56 , and a (Spearman) rank correlation of 0.33 .

Given the high correlation in levels and changes between the two measures it should not seem to matter too much which measure one uses. And indeed the empirical results presented below are robust to either measurc. One reason, however, to favor the Polity IV measure over the Freedom House measure, especially when looking at within-country changes, is the following. The documentation for the Freedom House data states that "methodological changes have been effected periodically." Further research revealed that in at least two years (1989-90 and 1993-94) the methodology used to convert raw points on each question to the scaled score changed. When the changes are effected the past scores are not revised to make them consistent with the current methodology. A look at the details in one of the years of change revealed that the problcm could be potentially significant: for 25 countries in the 1993-94 publication the change in the country score was purely for methodological reason while there was no change in "rcal world events." Due to these periodic methodological changes in the Freedom House measures they may be more apt for comparing democracy across countries for any given year rather than for comparing changes in democracy within countries over time. Since a great deal of the thrust in this paper is on explaining the within-country variation, because of unobservable country-specific effects, the Polity IV measure is emphasized. The Polity IV measure while not ideal either, seems to suffer less from this problem since the it has the kind of property which is needed: a backward looking effort to make sure the methodology used to convert the component variables to the overall democracy score is the same for all years (and of course all countries). The notes to the data set also discuss the results of several inter-coder reliability tests conducted to ensure consistency in the cross-country dimension of the data. These tests, the documentation reports, took the form of taking a common group of countries and getting different researchers to code them, and then reconciling the differences, before the actual codings were done. The purpose of the reconciliation was that by discussing the differences in their respective scoring, each group would converge in their interpretation of the guidelines. ${ }^{15}$ Table 2 gives the summary statistics for the common sample for both measures

\footnotetext{
${ }^{15}$ There is one other reason to prefer the Polity IV measure when focusing on the within country variation. The FH measures are compiled every year. The identity of the coder for any given country can potentially change from year to year. As such they are likely to have more noise because of differences in interpretation by
} 
of democracy. The overall mean for both scores is quite close to $1 / 2$ for both measures. The statistics also show that the indices of democracy vary much more across rather than within countries. As discussed below the smaller within-country variation is likely to result in bigger standard errors for the estimated coefficients in the fixed effects specification.

Table 3 illustrates the same point in another way by presenting the transition probabilities for the pooled cross-section time series data on the PIV democracy measure. As seen, most of the weight in the matrix is on the diagonal: country democracy ratings change quite infrequently. Table 4 presents non-parametric evidence on the bivariate relationship between changes in democracy index and changes in social sector spending. It identifies episodes of changes in the Polity IV democracy index by an amount indicated in the first column. For each set of country-years identified for each such threshold of change in the democracy index, it then selects those cases for which the democracy index remain unchanged two years prior to and two years after the change. The first row of the table thus indicates that there were two such countries (in the sample for which both the spending data and the democracy data were available) where democracy index fell by more than 3 points and where it was stable two years prior to and two years after the change. Similarly, the fourth row shows that there were 10 such cases in which democracy index fell by at least one point. For each of these cases I then calculate the mean of the sum of education and health spending (as percent of GDP) for the two years prior to the change and for the two years after the change. The last column then reports the median change in the two-year mean spending before and after the change in the democracy index. Appendix Table 1 lists each episode identified by the level of change in the democracy index. Table 4 indicates several things. First, there are many more cases of increases in democracy in this period (1985-1998) relative to decreases. Thus the summary statistics for the cases of decreases in democracy are likely to have bigger confidence intervals around them. Second, it shows that for all but one of the 8 cases the median change in social sector spending after an episode of change in democracy is in the expected direction. Episodes of increases in democracy are associated with increases in social sector spending and vice versa. Since the number of observations per episode is quite small, the evidence cannot be pushed too far. Thus it is difficult to make inferences about the linearity of the relationship based on the pattern of figures in the last column.

\section{Other variables}

While Table 4 presents suggestive evidence for the relationship between democracy and social sector spending the next section presents more formal evidence, controlling for the other potential determinants of social sector spending. The controls used are the following:

different coders of the guidelines for giving raw points to each country on each checklist. In the PIV revision groups of countries are assigned to groups of analysts. Then even if different coders have different biases in interpretation of the guidelines, if such a bias for any given coder for a particular country assigned to her is constant and present in the ratings for all years of the country, it would simply drop out in a fixed effects specification. 
(i) $\log$ of real per capita GDP from Summers-Heston, since income is likely to be an important determinant of government spending and its allocation; (ii) $\log$ of the share of trade (imports plus exports) in GDP, as pointed out by Rodrik (1998) to be an important determinant of government spending; (iii) percent of the population urbanized, as urbanization can have implications for government spending because of economies of scale considerations and because more urbanized populations may be able to organize better to lobby for greater government services; (iv) age-structure of the population captured by the share of population aged 14 years or younger, as the exiting literature points this to be an important empirical determinant of government spending; (v) the illiteracy rate to capture a component of the demand for social sector spending; and finally (vi) military spending as a ratio to GDP to capture an arguably exogenous component of government spending. Appendix Table 2 provides the sources and summary statistics for these variables.

\section{REgRESSION RESUlTS}

The basic specification used in the model is:

$$
s_{i t}=\alpha_{0}+\alpha_{1} d_{i t}+\alpha_{2} g_{i t}+\alpha_{3} \log \left(y_{i t}\right)+\sum_{k=1}^{K} \beta_{k} Z_{k i t}+\mu_{i}+\varepsilon_{i t}
$$

where $s_{i t}$ is a measure of social sector spending for country $i$ in year $t, d$ is an index of democracy (from either the Freedom House or Polity IV dataset) on a $0-1$ scale with 1 representing the highest rating for democracy, $g$ is total government spending as percent of GDP, $y$ is real per capita income (Summers-Heston dataset), $Z_{1}, \ldots, Z_{K}$ are other plausible determinants of social sector spending, $\mu_{i}$ is a country specific effect, and $\varepsilon_{i t}$ is a IID stochastic disturbance. Social sector spending is taken to be education and health spending and I report results on education and health individually as well as their sum. Each of the three measures of social sector spending (education, health, education + health) is scaled in one of two ways: (i) as a share of total government spending; and (ii) as a share of GDP. Since we are controlling for total government spending, each measure attempts to get at the total magnitude of resources devoted to social sectors.

Differences in interpretation of the country-specific effect $\mu_{i}$ determine whether (1) should be estimated in a cross-section regression or as a fixed effects model. A large part of the existing empirical work on government spending consists of estimating this equation in cross-section regressions. I therefore first present results based on the pure cross-sectional variation for total government spending (as share of GDP) and social sector spending. However, estimating this equation in the cross-section is problematic because of the presence of country-specific unobservables that are likely to be correlated with the error term. Such factors can include different historical and institutional factors specific to each country as well as differences in methodology and coverage of social spending statistics. As long as these factors are invariant over time they would be completely absorbed in the fixed terms in a fixed effects model. Moreover, for the purposes of policy recommendations, significant 
results based on the within country intertemporal variation can carry more weight. The statement that a more democratic country spends more on education and health than a less democratic country has less bite since skeptics can argue that unmeasurable country specific factors can potentially account for the explanation: country $A$, which is rated more democratic than country $\mathrm{B}$, spends more on social sectors than country $\mathrm{B}$ because it has a better institutional endowment than country $\mathrm{B}$ which has led to both more democratic institutions and more spending on social sectors. The statement that for any given country periods of greater democracy are associated with higher allocation of resources to social sectors has more import since institutional factors are probably constant over the period.

While fixed effects specifications have these superior qualities, it is generally hard to get precision in estimated coefficients in fixed effects models since the right-hand-side variables of interest in general vary more across countries rather than within countries over time. As was documented above, this is the case for the democracy measures as well. It is also difficult to get a long enough time series for a set of countries to exploit the intertemporal dimension in a meaningful way. Using the new spending data described above, I am able to put together a much larger panel data-set which goes towards mitigating these problems. The next set of results therefore use a fixed effects specification and I provide results for the determinants of the within-country variation of social sector spending. Overall, two interesting relationships emerge: one with respect to democratization and the other with respect to total spending. After presenting the basic results on social sector spending I then present the results from several robustness exercises. These include (i) imposing consistency in the level of coverage and source of the spending data; (ii) examining outliers, (iii) using alternative measures of democracy; and (iv) addressing concerns of serial correlation in the error term in the specification. After demonstrating that the basic partial correlation is robust to these considerations, I next discuss whether there is evidence to suggest that these correlations can be interpreted causally. Results from instrumental variables estimation and regressions in first differences suggest that the causation runs from democracy to social sector spending. Finally, I discuss the difference in the pure cross-sectional and within country results and advance one interpretation consistent with this pattern of results.

\section{A. Basic Results}

Table 5 shows the regressions for total government spending as a percent of GDP. The first two equations report the estimation using country means and the second two show the estimation from fixed effects. For each estimation, the first regression uses only the democracy index and log of real per capita GDP as independent variables and the second adds control variables. Several interesting results emerge. First, with respect to the coefficients significantly estimated, it matters whether one is identifying the effect in the cross-section or the intertemporal dimension as the coefficient on per capita income and agestructure switch signs. Second, democratization is not significantly related to total spending in the cross section and weakly (in terms of precision) related to spending in the within estimator. Although one cannot make too much of the result since it is only weakly 
significant when controls are included, it is interesting that greater democratization is associated with smaller total spending. ${ }^{16}$ The relationship between total spending and democracy is not the focus of examination here but these findings are consistent with the literature on the size of government which finds that greater direct democracy is associated with smaller size of the public sector (e.g. Matsusaka (1995)). Per capita income is significant in the regressions without the controls and seems to be proxying for other variables. Openness is a significant predictor of government size in both the cross-sectional and the within country variation (Rodrik (1998)), although the estimated magnitude of the effect halves in the fixed effects estimation. Finally, age structure and illiteracy rate turn out to be significant predictors of government spending. That the coefficient on age structure switches sign and is significant indicates the importance of country specific effects. If income is not controlling very well for the level of development, the negative cross-sectional relationship could be emerging from poor countries with lots of young people and small public sectors, and rich countries with bigger governments and more aged populations. The fixed effects specification shows that increasing the share of the young in the population is associated with greater government expenditures.

Turning to social sector spending, Table 6 presents the results from the between regressions for education and health spending (scaled alternatively by total government spending and GDP). Both specifications control for total government spending as a percent of GDP. Regressions 2 and 4 show a relationship between health spending and democracy, but the subsequent equations show that this relationship is not robust to controlling for other plausible determinants of government spending in social sectors. As expected, military expenditure is strongly and negatively associated with spending in social sectors, across countries. Regressions (5) and (7) also show the proportion of young in a population as a significant determinant of education spending, which is also reasonable. Overall, the results show that there isn't a statistically significant relationship between democracy and social sector spending in the pure cross-section.

Table 7 shows the results from the fixed-effects specification. The democracy variable is strongly significant in all four specifications for social sector spending controlling for total government activity and real per capita GDP. The slope effects for both education and health spending are quite similar. The next four regressions show that the coefficient falls somewhat in magnitude when the controls are included, and in one case (share of education spending in total GDP) becomes insignificant. For a given country, an increase in the democracy index from the worst rating to the best rating ( 0 to 1$)$ is associated with education getting 1.1 percent more, and health 1.4 percent more, of the government budget. In terms of shares of GDP a similar increase in the democracy index is associated with a 0.17 percent increase in health spending. Interesting findings also emerge with respect to how social sector spending reacts to changes in total spending. The second row of the table (all eight columns) shows a very robust relationship; an increase in total government spending (as share of GDP)

\footnotetext{
${ }^{16}$ Dropping the controls which are not significantly estimated does not recover statistical significance on the democracy and per capita income variables in the fixed effects specification.
} 
is associated with a reduction in the share of social sector spending in total spending. Social sector spending increases when total spending increases but by not as much as the other components of spending as the last two regressions show. Conversely, the coefficients imply that social sector spending is relatively protected during times of fiscal contractions-it falls but by not as much and its share in total spending rises. A natural question which arises is whether this relationship is symmetric with respect to fiscal expansions and contractions. To examine this I regress the change in social sector spending (education plus health) as share of total spending $(s / g)$ on a constant, the change in the share of total spending in GDP $(g / y)$, an intercept and slope interaction for whether government spending increased, and a complete set of country dummies. The coefficients are:

$$
\Delta(s / g)_{t}=0.26-0.28 \Delta(g / y)_{t}+0.03 D_{\Delta>0}-0.06 \Delta(g / y)_{t} \cdot D_{\Delta>0}
$$

Both the intercept effect $\left(D_{\Delta>0}\right)$ and the slope effect $\left(\Delta(g / y)_{t} \cdot D_{\Delta>0}\right)$ are however not significant, while the coefficient on $g / y$ is estimated with a t-statistic of $-7.62 .{ }^{17}$ The coefficient on $\Delta(g / y)$ is also very close in magnitude to the sum of coefficients on education and health shares of total spending in Table 7, which is reassuring. Including only the slope effect and/or including the change in log income per capita in the regression does not produce a significant result on the slope effect. Thus, the data reject the hypothesis that the relationship is asymmetric with respect to fiscal contractions and expansions. Finally, I also run the regression of the last two columns in $\log$ form. Let $\phi$ denote the share of social sector (education + health) spending in total spending, and $\gamma$ the share of total government spending in GDP. Hence social sector spending as share of GDP is $\phi \gamma$. In general $\phi$ may depend on total spending: $\phi=\phi(\gamma)$ and,

$$
\frac{\partial \log (\gamma \cdot \phi(\gamma))}{\partial \log (\gamma)}=1+\frac{\partial \log (\phi)}{\partial \log (\gamma)}
$$

In a regression of the log of social sector spending as share of GDP on the log of total government spending as share of GDP and all the other variables of Table 7, the estimated coefficient (standard error) on $\log (\gamma)$ is $0.57(0.05)$ in the fixed effects model. The null of social sector spending share (in the budget) being constant with respect to total spending is strongly rejected. In addition the implied elasticity of the social sector spending share with respect to total spending is -0.43 . As noted above results on the relationship with total government spending corroborate the findings of Mauro (2000).

The coefficients on other variables in Table 7 seem reasonable. Education spending, both as percent of total spending and as percent of output, is positively correlated with real per capita GDP. All measures of social spending go up with the log of population. The coefficient on openness becomes negative in the fixed effects specification. Education spending also increases with the percent of urbanization and the illiteracy rate. Interestingly,

\footnotetext{
${ }^{17}$ The country effects also are not jointly significant in the regression in changes.
} 
defense expenditure (as a percent of GDP) is only weakly related to social sector spending. This is not surprising since the results here (as opposed to Table 6) are driven by the withincounty variation - if military spending remains relatively constant because of national security considerations (determined say by history of conflict with neighboring countries) it is unlikely to affect changes in social sector spending. In the cross-section, however, countries which are lucky to have peaceful borders have more resources freed to spend on other sectors, and in particular social sectors.

There are several issues to be addressed with respect to the results shown in Table 7 . First, as was noted in the discussion in Section 0 , the government spending data vary by which level of government activity is covered, central or general. Although the country effects may absorb some of the variations due to these differences, they are unlikely to address problems arising from differences in level of coverage completely if (a) such effects do not enter equation (1) linearly and (b) if some countries have changed their methodology over the period. Thus, the next set of results use observations which come from the FAD dataset and which pertain to the central government level. In addition I also examine if there are outliers in the data influencing the results. Second, even though, as was argued above, the Polity IV measures may be more suitable for focusing on the intertemporal variation, it is interesting to see what are the results with the Freedom House measure of political rights, as used in Barro (1996), Wacziarg and Tavares (2000), and Wacziarg (2001), which have focused more on the cross-sectional variance. Third, since the spending data are yearly there might be business cycle effects giving spurious correlation or serial correlation in the error term (which would bias the standard errors). To address these issues I (a) present results with 3 period averages (1985-89, 90-94, and 95-98); (b) present results with averages over periods during which the democracy index does not change for a country; and (c) estimate the basic specification with robust standard errors which allows for correlation in the errors within countries (over time). I cover each of these areas below.

\section{Data Source, Level of Coverage, and Outliers}

Of the 78 countries with the underlying data for the last four regressions of Table 7,74 get their spending data from the FAD dataset and the remaining four (Spain, Greece, Italy, and Portugal) from GFS. In terms of the level of government to which the data pertain, 63 of the 78 countries have central government level data (including the 4 GFS countries). To get rid of possible biases from mixing the sources of data and mixing the levels of government activity covered, Table 8 shows the results of fixcd effects estimation when I restrict the sample to countries which get their data from the FAD dataset and which report central government spending. The cost is reduction in number of countries covered: 67 in the specification without the additional controls and 59 in the specification with controls. Table 8 shows that the results become stronger with this refinement of the underlying data. Both measures of social sector spending (education and health), expressed as shares of spending and as shares of GDP, are significant and the coefficients, particularly on education expenditure as a share of GDP, become bigger. Since pooling the data from different sources and for different levels of government may be problematic I focus on the FAD data pertaining to central government level spending for all subsequent regressions. Another 
possible concern, particularly by observing the jump in the coefficient in the education regression (column (7) in Table 8 vs. Table 7), is the presence of influential observations. Figure 6 presents a partial scatter for the coefficient estimated on the democracy index in the regression for education expenditure as a share of GDP (equation (7) in Table 8). The outlier at the bottom-right is Gambia. Excluding this influential observation makes the coefficient (standard error) on the democracy index increase to $0.57(0.14)$ in the regression for education spending as percent of GDP. Looking at the partial scatter, however, several other observations could potentially be considered "outliers." To explore this systematically, I calculate the DFbetas (the difference between the regression coefficient with and without the $j^{\text {th }}$ observation, scaled by the standard error of the coefficient) for the democracy variable and drop the observations for which $|D F b e t a| \cdot \sqrt{N}>2$, as suggested in Belsley et. al. (1980, p. 28), and where $N$ is the number of observations in the regression. Using this criteria leads to dropping 30 observations from the original 574 in equation (7) of Table 8 . The estimated coefficient (standard error) on the democracy index changes to $0.551(0.154)$ which is significant at 1 percent. Table 9 repeats this exercise for all dependent variables in Table 8 and presents the results on the two main variables of interest: the index of democracy and share of government spending in total output. Additionally, Table 9 also presents the results for the sum of education and health spending. In all cases, the results in terms of magnitude and significance become stronger on the democracy variable when "outliers" are excluded. Results on government spending remain remarkably stable when a similar DFbeta procedure is applied to this variable to exclude potential outliers. The table also shows that the bigger difference in the coefficients presented in Table 9 comes from whether Gambia is excluded or included. Since the results are robust to a systematic treatment of influential observations, I exclude Gambia from the sample for the purposes of making inferences about the magnitude of the relationships and from all subsequent results.

\section{Alternative Measure of Democratization}

As discussed above another measure of democracy used in the empirical literature is the Freedom House measure of political rights, although it may not be as apt for intertemporal comparisons because of reasons noted in the discussion above. For the sake of comparisons to existing papers using this variable, shows the result of fixed effects estimation using this index, which has been converted to a $0-1$ scale with 1 representing the highest rating for political rights. To conserve space I present results with the complete list of controls. In all except one specification, the measure of democracy is significant at 1 percent-for equation (3) the p-value is 0.052 for the coefficient on the democracy variable. The magnitudes are harder to compare across the two indices since they may be capturing different aspects of the democratic process. A movement from the worst to the best rating in the $\mathrm{FH}$ measure of democracy is associated with an increase of 4.5 percent in the allocation to social sectors in the total budget, and 0.70 percent in social sector expenditures as percent of GDP. Results on how the budget share of social sector spending responds to changes in total spending is also consistent with the previous results. 


\section{Business Cycle Effects and Serial Correlation}

Table 11 pulls together the results for examining the sensitivity of results to potential problems due to business cycle effects and potential serial correlation in the error term. First, and primarily to address concerns of spurious correlation due to business cycle effects-and as is the convention in the existing empirical literature on social sector spending using annual data (e.g. Lindert (1994, 1996)) - I construct averages of the left hand side and right hand side variables for the following periods: 1985-89, 90-94, and 95-98. Since the number of years for which data is available for each of these periods varies by country I weight each observation by the number of observations underlying the construction of the average. Thus a computed average for a country for a period using 5 years of data gets more weight than one using, say, 2 ycars of data. Using these averages in a specification with country effects would dampen the effects of serial correlation. The cost however is a reduction in the number of intertemporal observations available per country for estimating the within effect, resulting in bigger standard errors. The first two columns of Table report the results and show that the results are robust to this correction. They also show that the pattern on coefficients overall remains the same as using annual data. Government spending, urbanization and illiteracy turn out to be other important determinants of social spending as share of GDP. For brevity $I$ also focus on total social sector spending (education plus health) - results on the individual sectors are very similar. Compared to Table 9 the standard errors are bigger and the increase could be coming from two possible sources: elimination of some bias in the previous results duc to serial correlation and/or the smaller number of observations used in the estimation as a result of averaging. The coefficients however also rise in magnitude and the results are strongly significant. Since these regressions use 5 ycar averages, I also included the BarroLee measure of average years of school attainment in the population which is available at 5ycar intervals. The estimated coefficient on it however was not significant and its inclusion did not substantially alter the results on the democracy and total government spending variables.

Next, I subject the results to a different test in a similar vein. As was documented above the democracy indices for countries change relatively infrequently. The typical time series for a country for the democracy index looks like a flat line with a jump at some point followed by another flat line (and so on). If spending measures also show persistence because of serial correlation, then in the estimation using the within transformation on annual data, one could arguably be giving too much weight to the multiple observations for a given level of the democracy index. That is, suppose that a country has $T_{i}$ years of data and for the first $T_{i} / 2$ years its democracy index is $d_{1}$ after which it changes to $d_{2}>d_{1}$ and remains at that level for the remaining $T_{i} / 2$ years. Suppose also that social sector spending in this country (the orthogonal component from the effect of the other RHS variables) is around $s_{1}$ for the first $T_{i} / 2$ years and then around $s_{2}>s_{1}$ for the remaining years. Then, using annual data (and after the within transformation), there are $T_{i} / 2$ points in the upper right quadrant and $T_{i} / 2$ in the lower left, even though, one could argue that each cluster of $T_{i} / 2$ observations really represents one piece of new information each. Although this pattern would be entirely 
consistent with the hypothesis being put forward here-that democracy is a significant determinant of social sector spending - the test I undertake is to stack the odds against finding evidence consistent with this hypothesis by using these two clusters as one observation each thercby giving less weight in the determination of the slope coefficient. More formally, let $d_{i t}$ denote the value of the democracy index for country $i$ in year $t$, and let $D_{i}$ denote the set of unique values taken by $d_{i t}$ for country $i$. Define a period $t_{i j}$ as the set of years for which $d_{i t}$ takes a unique value $d_{j} \in D_{i}$ :

$$
t_{i j}=\left\{t: d_{i t}=d_{j} \text { for } d_{j} \in D_{i}\right\}
$$

Then, starting with the original equation,

$$
s_{i t}=\alpha_{1} d_{i t}+\alpha_{2} x_{i t}+\mu_{i}+\varepsilon_{i t},
$$

where $x_{i t}$ collects all the other right-hand side variables including the constant and $\varepsilon_{i t}$ is IID with variance $\sigma_{\varepsilon}^{2}$, and defining $z_{i t_{i j}}$ as the average over the period $t_{i j}$ for a country $i$ for any variable $z$ :

$$
z_{i t_{i j}}=\frac{1}{\left|t_{i j}\right|} \sum_{t \in t_{i j}} z_{i t}
$$

we get

$$
s_{i t_{i j}}=\alpha_{1} d_{i t_{i j}}+\alpha_{2} x_{i t_{i j}}+\mu_{i}+\varepsilon_{i t_{i j}}
$$

Since the $\varepsilon_{i t}$ are HD, $\operatorname{var}\left(\varepsilon_{i t_{i j}}\right)=\frac{\sigma_{\varepsilon}^{2}}{\left|t_{i j}\right|}$ and (2) can be estimated with weighted least squares with a complete set of country effects where each observation is weighted by $\left|t_{i j}\right|$, the number of years in the period over which the average is taken. Thus (2) consists of a panel with $\left|D_{i}\right|$ observations per country. The middle two columns of Table 11 show the results. Note that (2) is estimated with only $39(107-59-10)$ degrees of freedom. Plausibly due to the sharp reduction in the degrees of freedom, the standard errors for all variables rise considerably and compared to the annual and 5-year averages results many variables lose their significance. The coefficient on democracy remains significant.

Finally, to address problems of inference arising from potential correlation of errors within countries over time, the last two columns of Table 11 present the results using annual data where I allow the $\varepsilon_{i t}$ 's to be correlated within countries in the estimation using a robust variance calculation. Note that the coefficients are the same (necessarily so) as those reported in Table 9 but the standard errors are nearly twice as big. The pattern is similar to the first two columns and democracy is significant at conventional levels. The results on the democracy index are significant at conventional levels. I also estimated (1) using White (1980) robust standard errors without specifying structure on the variance-covariance matrix. 
The results in terms of significance were very similar. In particular, the democracy and government spending variables were significant at conventional levels.

\section{B. Causality}

Given a significant partial correlation between democracy and social sector spending, to what extent can it be considered a causal relationship? First, with a complete set of country fixed effects included in the model, problems of endogeneity are likely to be contained, at least, as compared to cross-sectional estimates, since more components of what would otherwise be in the residual are being controlled for. Second, while democracy indices could in general be susceptible to changes in country economic conditions, they are more likcly to be affected by the overall level of cconomic development as captured by the level of real GDP, than social spending per se. There is a weak or non-existent statistical relationship between real GDP per capita and social spending. Hence it is difficult to think of a direct causal link from social sector spending to democracy. Democracy indices may be affected by social indicators (as opposed to social sector spending), such as educational attainment of the population, as analysts may weigh these factors in determining political awareness of the population which in turn might determine the degree of political competition. Again, however the literature on the relationship between spending and outcomes does not point to a strong relationship, so that even if social indicators might affect democracy ratings, social sector spending in a year is not likely to affect the democracy ratings for that country for that year. Moreover, social indicators change slowly so it is unlikely they would play a big role in producing the intertemporal variation in the democracy index.

More formally, to address endogencity it is hard to do so using the method of instrumental variables since it is difficult to think of instruments which would (a) predict the intertemporal variation in democracy and (b) be a variable which affects democracy but not social sector spending. The empirical literature on democracy in the context of economic growth points to per capita real income as one of the determinants of democracy. Barro (1996) comments "increases in the standard of living substantially raise the probability that political freedoms will grow." Real per capita income is also not significantly correlated with social spending from the results in tables 8-11, once the other controls have been included. Per capita real income is significantly correlated with democracy in a fixed effects regression of democracy index on income and all other controls used in the paper. The coefficient (standard error) is $0.43(0.09)$ with a t-statistic of 4.8 . Doubling of real income is associated with a 0.43 point increase in the democracy index. ${ }^{18}$ Thus I run the specification in (1) with a full set of country indicators and controls and instrument for democracy using log of per capital real GDP. Table shows the results. The standard errors are bigger as expected since IV is not efficient. What is striking is that the coefficient on democracy nearly doubles in magnitude. If the endogeneity was in the suspected direction of higher social sector spending leading to higher democracy indices, then, under the identifying assumption, we would have expected a reduction in the magnitude of the coefficient. To the extent, then, that within-

\footnotetext{
${ }^{18}$ Note, the underlying data consists primarily of developing countries.
} 
country changes in income are good instruments for changes in the democracy index for a country, the OLS estimates of (1) seem to be underestimating the effect of democracy on social sector spending.

A second way in which I try to address causality is in a Granger sense. Starting with (1), I difference it to write:

$$
\Delta s_{i t}=\alpha_{1} \Delta d_{i t}+\alpha_{2} \Delta g_{i t}+\alpha_{3} \Delta \log \left(y_{i t}\right)+\sum_{k=i}^{K} \beta_{k} \Delta Z_{k i t}+\Delta \varepsilon_{i t},
$$

and I regress the change in social sector spending on the change in government spending, the change in log per capita income, and the change in the democracy index. I also try including the controls but they are generally not significant. In addition I also tried including a complete set of country effects in the above specification to capture country specific trends in changes in social sector spending. The joint test on the significance of the county effects never rejected, or even came close to rejecting. The first and fourth columns of Table show the results of the estimation. The coefficients on the contemporaneous changes in the democracy index are of the expected sign and close to magnitude in the previous estimates but not significant. The coefficients on government spending are strongly significant and remarkably close to the estimates in the levels regressions. Also, consistent with the estimation before, per capita income is not significant even though further controls are not present. Aside from the democracy variable the pattern of coefficients is close to what we observed before. The $2^{\text {nd }}$ and $5^{\text {th }}$ columns replace the contemporaneous change in the democracy index with the change lagged one period. The coefficients on the change in democracy index for both measures of social sector spending become stronger in magnitude and significant at 5 percent. The increase in magnitude suggests that changes in democracy index are strongly correlated with subsequent changes in social sector spending. The $3^{\text {rd }}$ and $6^{\text {th }}$ columns confirm that we get no relationship when we regress changes in social sector spending on future changes in the democracy index.

To summarize there is a robust empirical relationship between social sector spending and (a) total government spending relative to GDP and (b) indices of democracy in a country. The coefficients from Table 9 and Table suggest that a change from the lowest to the highest rating for democracy for a country is associated with a increase of central government social sector spending of somewhere between 0.78 percent to 1.5 percent of GDP. In terms of the share of the budget, such an increase in democratization is associated with a increase of 4.7 percent to 6.7 percent in the share of resources devoted to social sectors by the central government.

\section{Interpretation}

What explains the difference between the pure cross-sectional and the within-country effects documented above? One interpretation consistent with these two sets of observations focuses on the role of decentralization. If it is the case that (a) most social sector spending occurs at the sub-national level, rather than the central government level, and (b) that more 
democratic countries are also more decentralized, then the relationship between social sector spending and democracy is difficult to identify in the cross-section since the extent of decentralization is an omitted covariate. If $\theta$ denotes the share of sub-national government expenditure in total (central plus sub-national) government expenditure then central government spending on social sectors (denoted $s^{C}$ ), the variable which is available from the data for a large number of countries, is $(1-\theta) s(d)$ and allowing $\theta$ to depend positively on the level of democracy $d$,

$$
\frac{\partial s^{C}}{\partial d}=\left(1-\theta_{i}\right) \frac{\partial s}{\partial d}-s \frac{\partial \theta}{\partial d}
$$

where $s$ is total government spending on social sectors. If the cross-sectional regression is interpreted as allowing $\theta$ to vary across countries, then, assuming that $\frac{\partial s}{\partial d}>0, \frac{\partial \theta}{\partial d}>0$, we get an ambiguous prediction for the response of central government social sector spending to democracy. On the other hand, since the degree of decentralization is likely to change slowly over time in a country, the fixed effects estimation can be interpreted as holding $\theta$ constant which then allows for the relationship between democracy and social sector spending to be identified. This interpretation relies on there being a positive cross-sectional association between measures of democracy and the extent of decentralization in a country. To shed evidence on whether this is actually the case I use data from Beck et. al. (1999)'s Database of Political Institutions (DPI) which covers 177 countries for the period 1975-1995. As part of their database they provide the following variables related to decentralization:

Author Do Sub-national governments have extensive taxing, spending or regulatory authority? $(1=$ yes $)$.

State Are the state/ province governments locally elected? $(0=$ neither the local executive nor the local legislature are directly elected by the local population that they govern; 1 = either is directly elected and the other is indirectly elected (e.g. by councils at subsidiary levels of government) or appointed; $2=$ both directly and locally elected).

Muni Are the municipal governments locally elected? $(0=$ neither the local executive nor the local legislature are directly elected by the local population that they govern; $1=$ either is directly elected and the other is indirectly elected (e.g. by councils at subsidiary levels of government) or appointed; $2=$ both directly and locally elected). If there are multiple levels of sub-national governments, the lowest level is considered "municipal."

There is a strong positive correlation between these measures of decentralization and both measures of democracy used in this paper. For each of these four measures, Table shows the mean for the democracy variables by the value of the decentralization variable for the pooled sample. Countries where sub-national governments have extensive taxing, 
spending or regulatory authority have average democracy scores much higher than those where sub-national governments don't have this authority. Similarly, countries where state governments are locally elected, and hence which are likely to have a greater say in state social sector expenditures, have progressively higher averages for the democracy score. The differences in the means are coming almost entircly from the cross sectional variation since these measures of decentralization don't change very much over time: for at least 98 percent of the pooled observations for any of the four variables there is no change in the value of the variable from its value in the preceding year. For the few cases in which there is a change in the decentralization measure further examination revealed that there was a weak intertemporal association with changes in the democracy index. For the common sample, the variable Author does not change for any of the countries for the period covered. Of the 10 cases in which the variable State changed, 4 cases saw no major change in the Polity IV democracy index in the vicinity of the change (where "vicinity" is defined as $+/-3$ years), 1 saw a change in the opposite direction (more decentralization, fall in democracy index), and 5 witnessed a change in the expected direction. ${ }^{19}$ Similar findings emerge from examination of individual changes in the Muni variable. Thus there is a strong cross-sectional relationship, and a weak intertemporal relationship (plausibly because changes in democracy take time to lead to changes in decentralization) between democracy indices and decentralization measures, as would be required for the interpretation of the difference in the cross sectional and intertemporal results put forward.

This interpretation also implies that the effect of democratization on total social sector spending (central plus sub-national) is being underestimated by a factor of $(1-\theta)$ in the regressions using the central government spending data. Note also that if decentralization is key to the explanation then even the between estimator using the general level government expenditure on social sectors should show the relationship between democratization and social sector spending. The problem with trying to test this prediction is the relatively few number of countries for which general government level data is available with a breakdown for social sector spending. There are 13 to 16 countries for which data at this level is available, depending on the number of other control variables used. Table 15 shows that indeed, even for this limited number of observations there is (i) a significant relationship between democratization and social sector spending in the pure cross section, and (ii) the estimated magnitude is much stronger than the estimates from the central government level fixed effects estimates, as predicted by this interpretation. ${ }^{20}$ These cross-sectional regressions (using country means) exclude the remaining controls for two reasons: the limited number of degrees of freedom available and the fact that the variables which have been omitted were

\footnotetext{
${ }^{19}$ The countries (years) in which the variable State changed are: Belgium (1994), Benin (1992), Colombia (1991), Ghana (1990), Laos (1989), South Africa (1994), South Korea (1992), Sri Lanka (1988), St. Lucia (1986), and Togo (1993).

${ }^{20}$ Fixed effects estimation using general government data does not give precise estimates because, as was discussed above, given the small inter-temporal variation in the democracy indices (as opposed to the crosssectional variation) a large number of observations is needed to get tight confidence intervals.
} 
not significant in a between regression which used all the controls. The size of the coefficient in the fourth equation implies that a country with the democracy index one (between) standard deviation (0.39) greater than another country has social scctor spending 0.35 standard deviations ( 3.4 percent) greater as a percent of GDP. This standardized coefficient is nearly twice the size of the standardized coefficient of 0.184 in the fixed effects regression of Table 9 using central government level data. In level terms these estimates imply that a country with the highest democracy rating on the Polity IV range, devotes on average 3.1 percent more of GDP towards education and health spending. As another check on the magnitude of the coefficient and whether it is consistent with the interpretation posed here, eq. (3) implies that the slope coefficient for the general government expenditure on social sectors should be $(1-\theta)^{-1}$ times the slope coefficient for the central government expenditure regression. Running the $4^{\text {th }}$ regression of Table 15 for the sample of countries for which central government expenditures are available (using fixed effects and same set of control variables) the estimated coefficient (standard error) on the democracy index is 1.03 (0.18). Next, to estimate $\theta$ I use GFS data to select the biggest possible sample of countries for which total government expenditure data are available at all three levels of government: central, state, and local. This yields 15 countries. ${ }^{21}$ For these countries I compute the average centralization ratio (central government expenditure divided by the sum of central, state, and local government expenditure) for each country for as many years as the data is available for (maximum coverage: 1970-1999) and then average it over the countries. This gives me an estimated $\theta$ of 0.67 . The implied slope coefficient for a regression using general government social sector expenditure is therefore $1.03 \times(1-0.67)^{-1}=3.12$. This is remarkably close to the estimated coefficient of 3.07 of Table.

\section{Conclusion}

This paper has demonstrated an important empirical determinant of social sector spending in a panel of countries. Democratization, as measured by changes in subjective indices of democracy, leads to statistically significant increases in social sector spending. A change from the lowest to the highest rating leads to somewhere between 0.7 percent to 1.5 percent greater central government spending on social sectors as percent of GDP. Estimates for general government spending suggest an increase of approximately 3 percent of GDP devoted to social sectors. The paper finds some evidence that the difference between the cross-sectional and fixed effects results can be reconciled by considering the role of decentralization of social sector spending. Results also show that social sector spending is more insulated than other spending from changes in the size of the budget. Increases in total spending are associated with less-than-proportional increases in social sector spending. Conversely, overall fiscal contractions are associated with less-than-proportional reductions in social sector spending - the share of social sector spending in total spending rises during fiscal contractions. I do not find any evidence that the relationship is asymmetric with respect to expansions and contractions.

\footnotetext{
${ }^{21}$ These 15 countries are: Australia, Austria, Bolivia, Brazil, Canada, Colombia, Germany, Malaysia, Mexico, Peru, South Africa, Spain, Switzerland, United States, and Yugoslavia.
} 
These findings open up several interesting areas of future research. Given that democratization is associated with social spending, an interesting related question is how different political institutions promote or discourage spending on social sectors. In particular, one particular area of research is to examine the effect of government fragmentation (in the sense of weak coalition governments) on social sector spending. Existing literature (e.g. Milesi-Ferretti et. al. (2001) and Persson and Tabellini (2000c)) has examined the implications for total government spending and the composition between transfers and general government consumption, but relatively little work exists on relating legislative and electoral institutions to social sector spending. Another interesting line of research is to examine the historical trends in social sector spending in OECD countries and to related them to political and economic factors. Such work could build upon Lindert (1994) and would nicely complement the findings in this paper. 


\section{REFERENCES}

Barro, Robert (1996), "Democracy and Growth," Joumal of Economic Growth, 1(1): pp. 1-27.

Belsley, D.A., E. Kuh, and R.E. Welsch (1980), Regression Diagnostics, New York: John Wiley and Sons.

Beck, Thorsten, George Clarke, Alberto Groff, Philip Keefer, and Patrick Walsh, "New Tools and New Tests in Comparative Political Economy: The Database of Political Institutions," World Bank Policy Research Working Paper No. 2283, The World Bank, Washington, DC.

Cashin, Paul, Paolo Mauro, Catherine Pattillo, and Ratna Sahay (2001), "Macroeconomic Policies and Poverty Reduction: Stylized Facts and an Overview of Research," IMF Working Paper (forthcoming), International Monetary Fund, Washington, DC.

Gupta, Sanjecv; Dicks-Mireaux, Louis; and Khemani, Ritha, "Social Issues in IMFSupported Programs," IMF Occasional Paper No. 191, International Monetary Fund, Washington, DC.

Gupta, Sanjeev; Verhoeven, Marijn; and Tiongson, Erwin (1999), "Does Higher Government Spending Buy Better Results in Education and Health Care?" IMF Working Paper No. WP/99/21, International Monetary Fund, Washington, DC.

Husted, Thomas and Lawrence Kenny (1997), "The Effect of the Expansion of the Voting Franchise on the Size of Government," Journal of Political Economy, 105(1): pp. 54-82

Inkeles, Alex (ed.) (1991), On Measuring Democracy, New Jersey: Transaction Publishers.

Lindert, Peter (1994), "The Rise of Social Spending, 1880-1930," Explorations in Economic History, 31(1): pp. 1-37.

Lindert, Peter (1996), "What Limits Social Spending?" Explorations in Economic History, 33(1): pp. 1-34.

Matsusaka, John (1995), "Fiscal Effects of the Voter Initiative: Evidence from the Last 30 Years," Journal of Political Economy, 103(3): pp. 587-623.

Mauro, Paolo (2000), "What Do Governments Cut?" mimeo, Research Department, IMF, Washington, DC.

Mauro, Paolo, (1998), "Corruption and the Composition of Government Expenditure," Journal of Public Economics, 69(2): pp. 263-79. 
Meltzer, Allan and Scott Richard (1981), "A Rational Theory of the Size of Government," Journal of Political Economy, 89(5).

Milesi-Ferretti, Gian Maria; Perotti, Roberto; and Rostagno, Massimo (2001), "Electoral Systems and Public Spending," IMF Working Paper WP/01/22, International Monetary Fund, Washington, DC.

Moore, Mick and James Putzel (1999), "Politics and Poverty: A Background Paper for the World Development Report 2000/2001," mimeo, Institute of Development Studies, University of Sussex, Brighton, UK.

Persson, Torsten and Guido Tabellini (2000a), Political Economics: Explaining Economic Policy, Cambridge and London: MIT Press.

Persson, Torsten and Guido Tabellini (2000b), "Comparative Politics and Public Finance," Journal of Political Economy, 108(6): pp. 1121-61.

Persson, Torsten and Guido Tabellini (2000c), "Political Institutions and Policy Outcomes: What are the Stylized Facts?" mimeo, Institute for International Economic Studies, Stockholm University, Stockholm, Sweden.

Ravallion, Martin (2000), "Are the Poor Protected from Budget Cuts? Theory and Evidence for Argentina," World Bank Policy Research Working Paper No. 2391, The World Bank, Washington, DC.

Rodrik, Dani (1998), “Why Do More Open Economies Have Bigger Governments?” Journal of Political Economy, 106(5): pp. 997-1032.

Saint-Paul, Gilles and Thierry Verdier (1993), "Education, Democracy and Growth," Journal of Development Economics, 42(2): pp. 399-407.

Snyder, James M. and Irene Yackovlev (2000), "Political and Economic Determinants of Changes in Government Spending on Social Protection Programs," mimeo, MIT, Cambridge, MA.

Tavares, Jose and Romain Wacziarg (2000), "How Democracy Affects Growth?" mimeo, Stanford University, Stanford, CA.

Wacziarg, Romain (2001), "Human Capital and Democracy," mimeo, Stanford University, Stanford CA.

World Bank (2000), World Development Report 2000/2001, The World Bank, Washington, DC. 
Figure 1

\section{Variation across countries in Social Sector Spending}
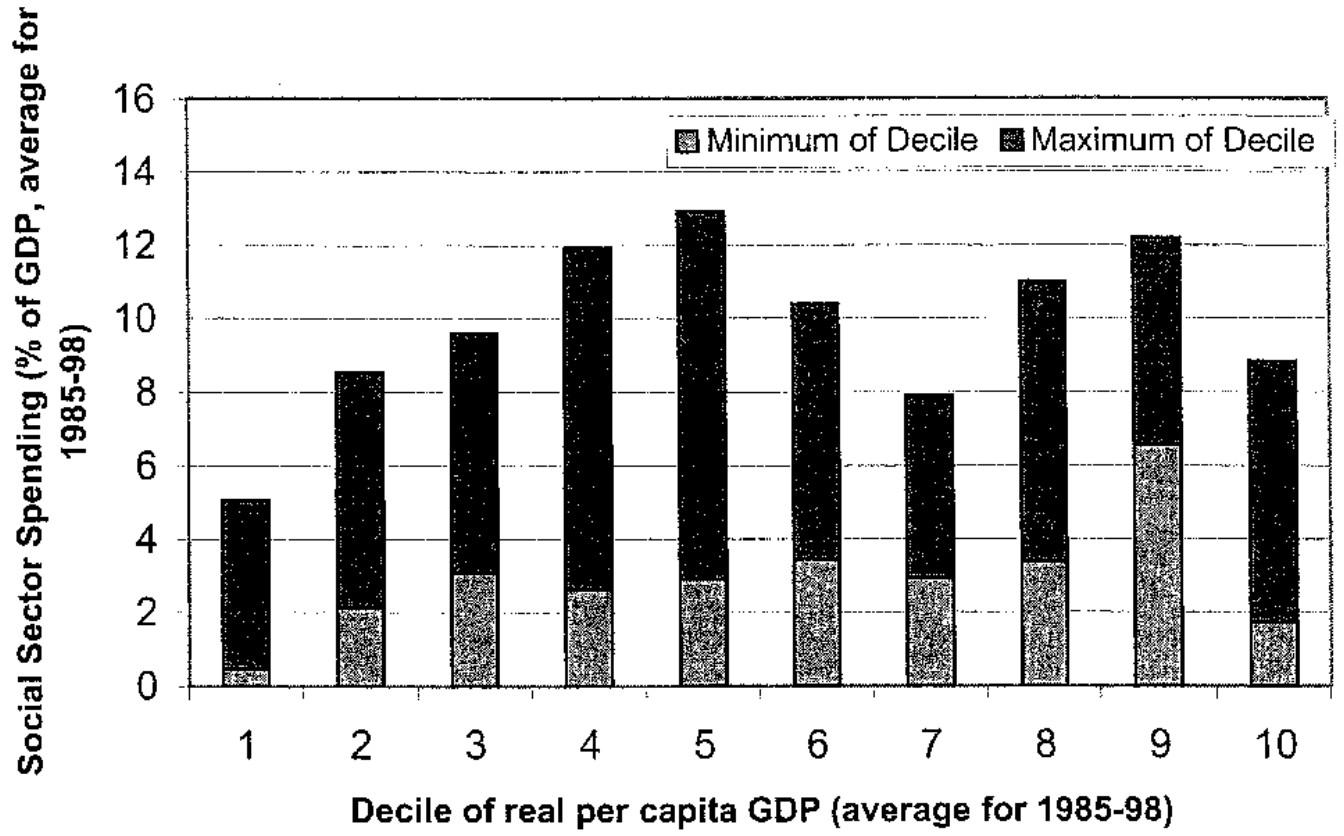

Note: Real per capita GDP (based on Summers-Heston) and central government social sector spending (defined as the sum of education and health spending) are averaged for each country for which at least 3 observations were available for the period $1985 * 98$. On average there are 10 yearly observations per country. Countries are then arranged in order of increasing real per capita GDP and bars report the max and min for social sector spending for each decile of countries. There are 10 countries in each decile. 
Figure 2

Within-country variation in Social Sector Spending, 1985-98

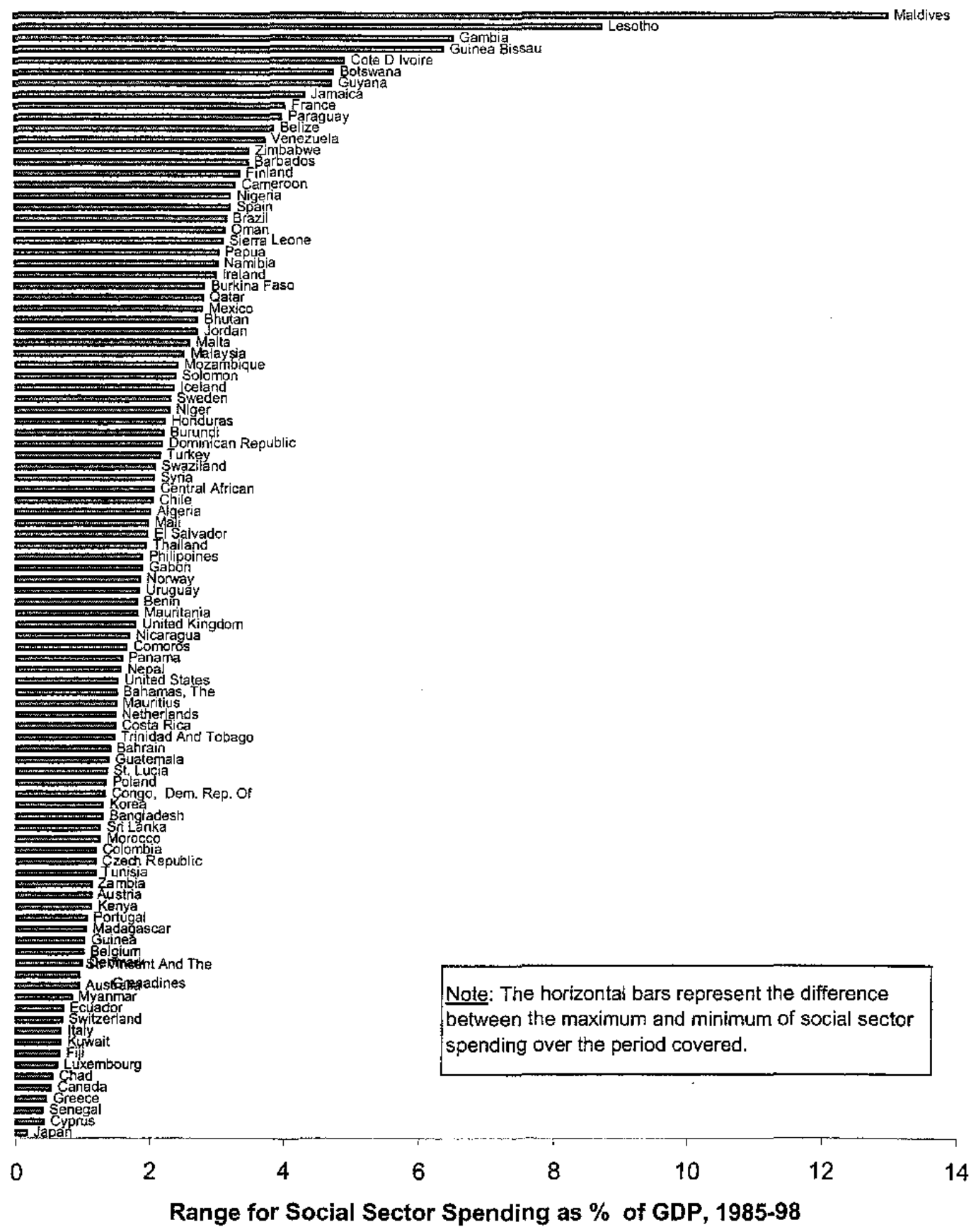


Figure 3

\section{Gross Primary Enrollment Rates by Decile of Education Spending}

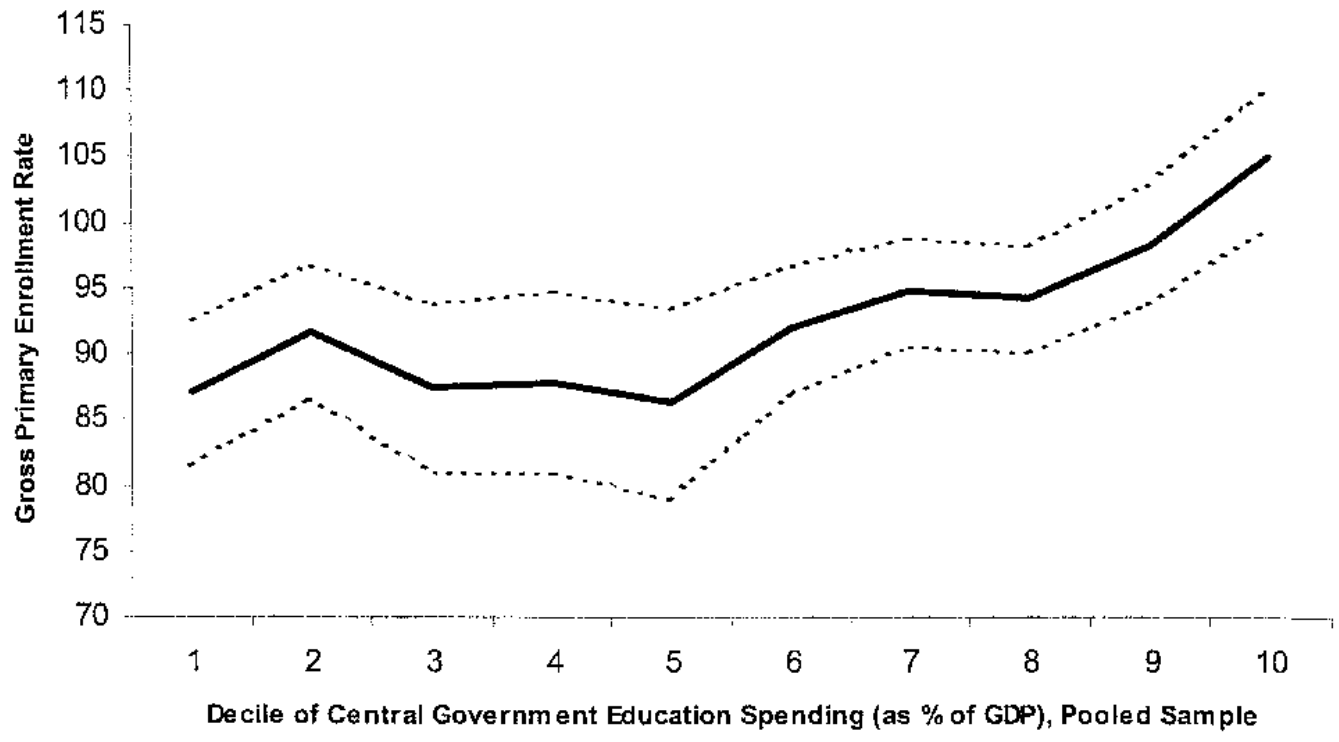

Note: Dashed lines represent $95 \%$ confidence interval for the decile means. Source of enrollment data is the Wortd Bank's Global Development Finance and Worid Development Indicators, as reported at The World Bank's Economic Grow th homepage (hltp:/ww w w w orldbank.org/research/grow th/). 
Figure 4

Infant Mortality Rates by Decile of Health Spending

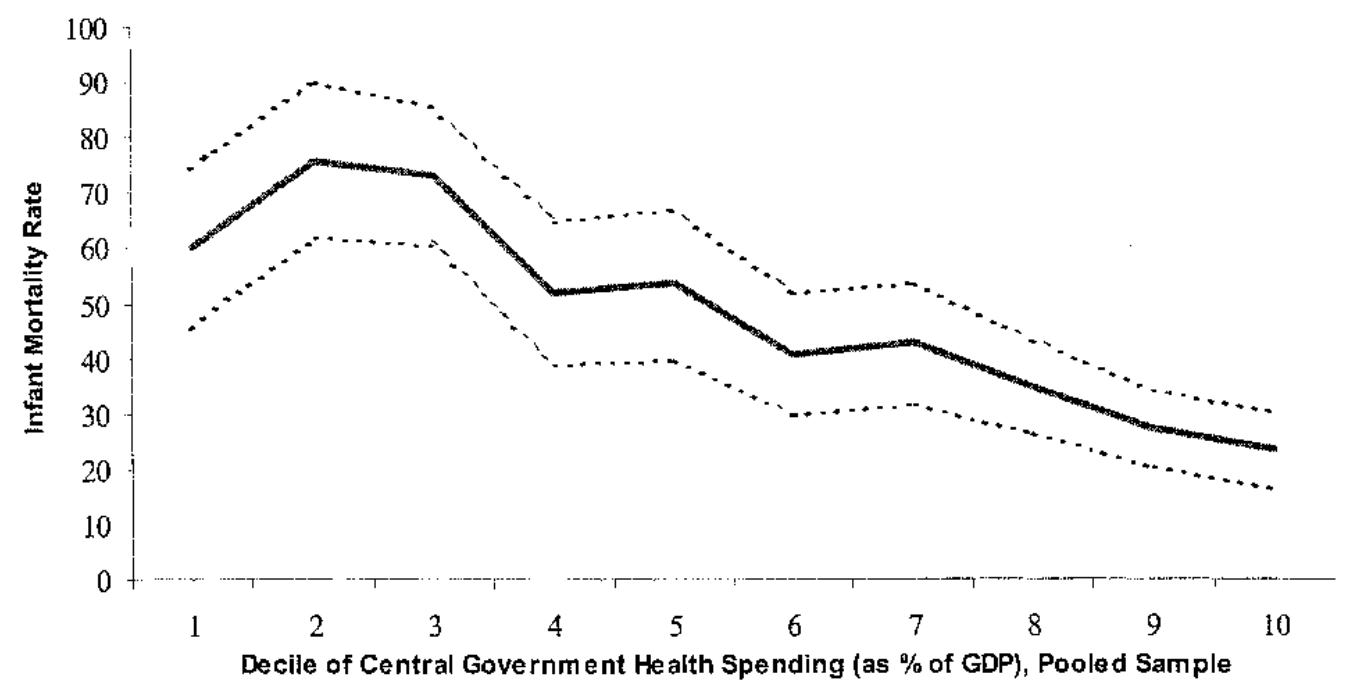

Note: Dashed lines represent $95 \%$ confidence interval for the decile means. Source of mortaility data is the World Bank's Global Development Finance and Worid Development indicators, as reported at The World Bank's Econorric Grow th homepage (http://w ww w orldbank.org/research/grow thl). 
Figure 5

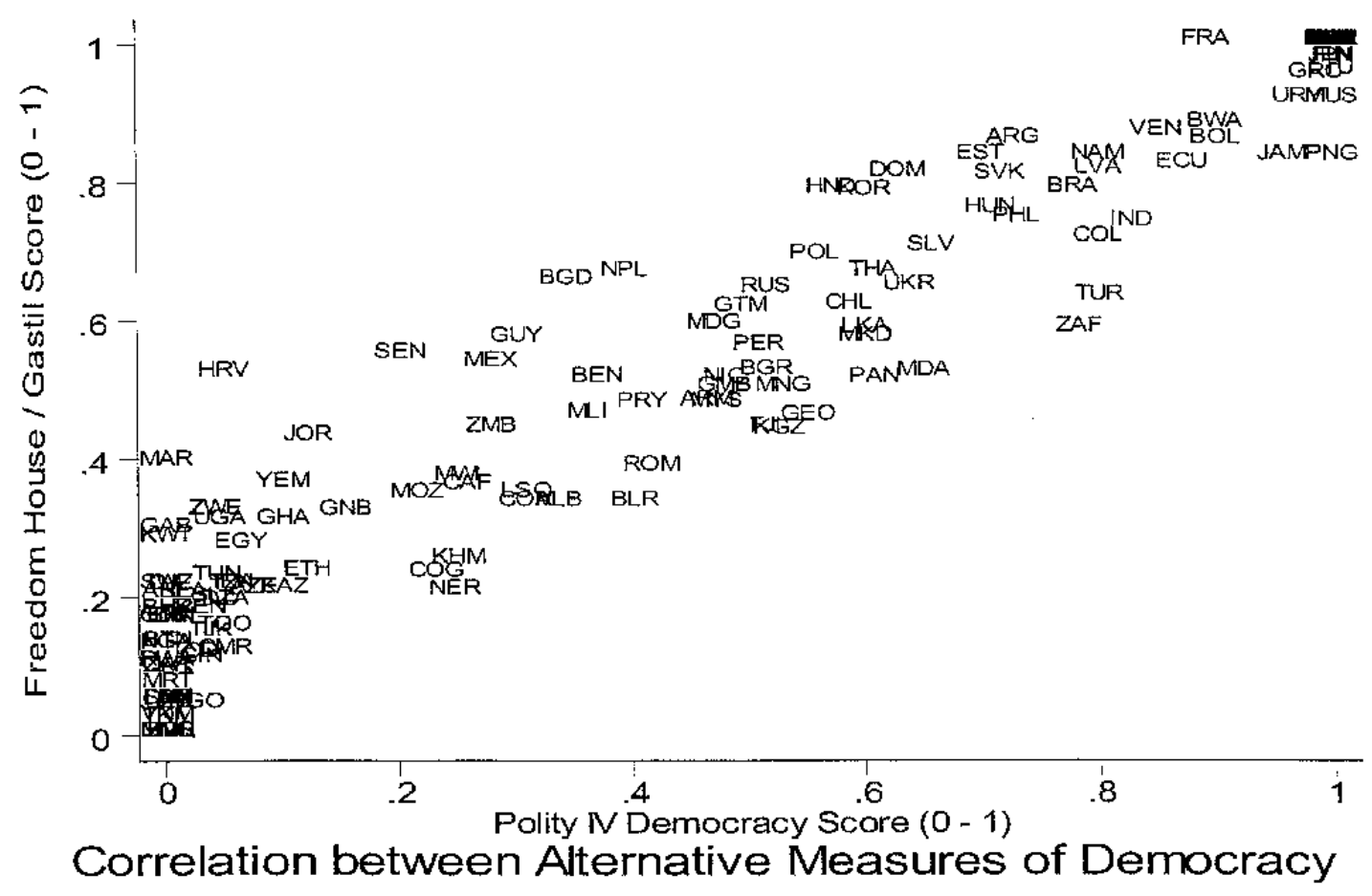


Figure 6

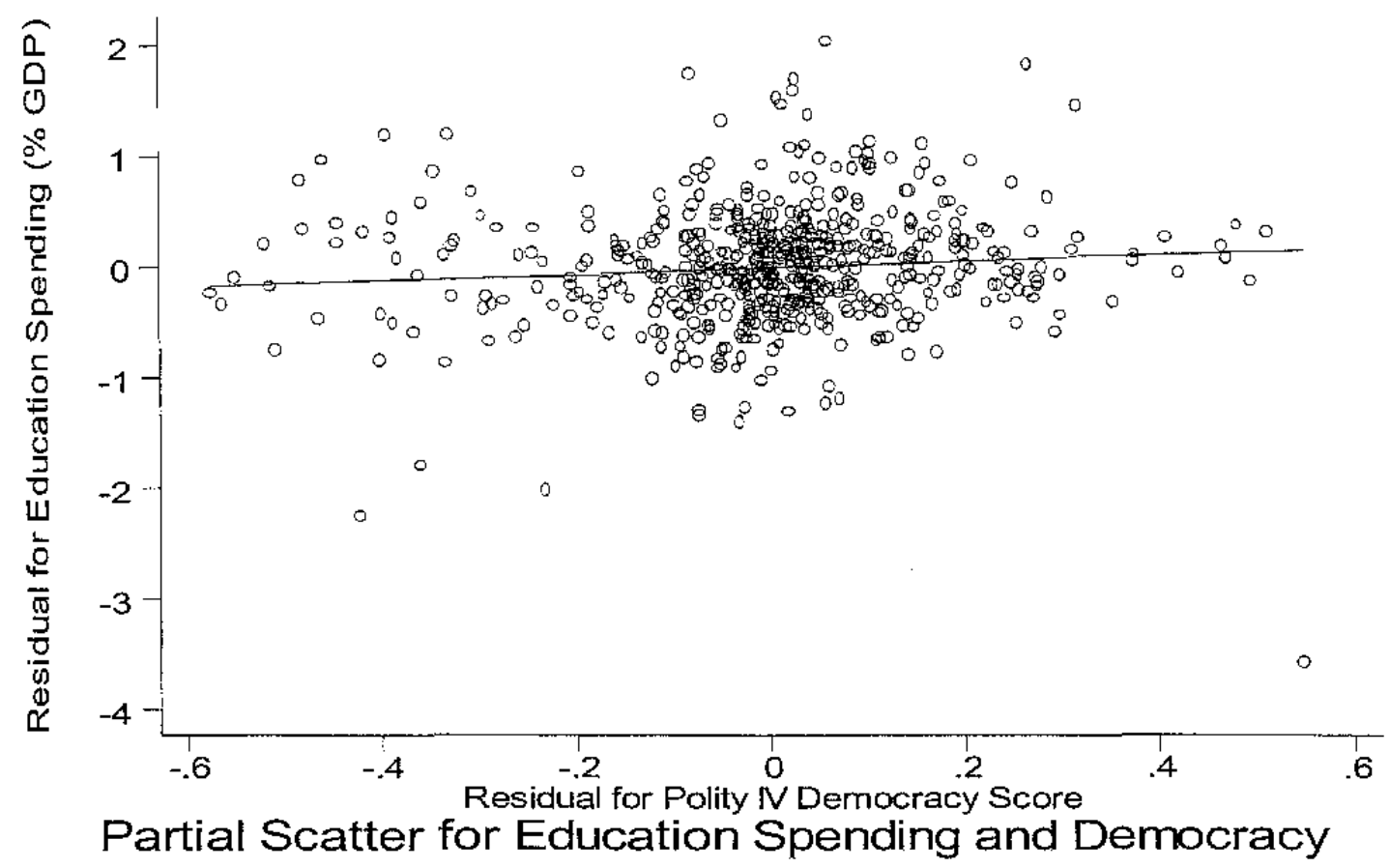


Table 1

Summarty Statistics for Government Spending Variables

\begin{tabular}{|c|c|c|c|c|c|c|}
\hline Variable & & Mean & Std. Dev. & $\operatorname{Min}$ & Max & Observations \\
\hline \multicolumn{7}{|l|}{ As $\%$ of GDP: } \\
\hline \multirow[t]{3}{*}{ 1) Total government spending } & overall & 31.81 & 13.32 & 5.10 & 100 & $N=1870$ \\
\hline & between & & 13.53 & 10.74 & 100 & $n=164$ \\
\hline & within & & 5.00 & 0.65 & 59.56 & T-bar $=11.40$ \\
\hline \multirow[t]{3}{*}{ 2) Education spending } & overalf & 4.00 & 2.29 & 0.04 & 29.63 & $N=1446$ \\
\hline & between & & 1.89 & 0.20 & 10.28 & $\mathrm{n}=147$ \\
\hline & within & & 1.21 & -1.66 & 25.41 & T-bar $=9.84$ \\
\hline \multirow[t]{3}{*}{ 3) Health spending } & overail & 2.51 & 1.90 & 0.01 & 16.57 & $N=1432$ \\
\hline & between & & 1.72 & 0.11 & 7.96 & $n=145$ \\
\hline & within & & 0.79 & -0.80 & 14.61 & T-bar $=9.88$ \\
\hline \multirow{3}{*}{$\begin{array}{l}\text { 4) Social sector spending } \\
\text { (Education + Health) }\end{array}$} & overall & 6.46 & 3.58 & 0.05 & 46.2 & $N=1415$ \\
\hline & between & & 3.02 & 0.48 & 18.24 & $n=145$ \\
\hline & within & & 1.87 & -2.32 & 39.99 & $T$-bar $=9.76$ \\
\hline
\end{tabular}

As $\%$ of total government spending:

5) Education spending

$\begin{array}{rllll}\text { overall } & 12.94 & 5.56 & 0.17 & 33.33 \\ \text { between } & & 5.08 & 0.63 & 27.13 \\ \text { within } & & 2.25 & 0.72 & 22.20\end{array}$

$N=1461$

$\mathrm{n}=147$

T-bar $=9.94$

6) Health spending

overall
between
within

7.72

4.58

0.04

30.28

$N=1448$

$\begin{array}{lll}4.22 & 0.53 \quad 23.05\end{array}$

$n=145$

7) Social sector spending

overall
between
within

20.59

$\begin{array}{ll}7.41 & 0.21 \\ 6.76 & 2.07 \\ 3.37 & 4.51\end{array}$

17.30

T-bar $=9.99$

54.96

41.30

34.25

$$
\begin{aligned}
N & =1430 \\
n & =145 \\
\text { T-bar } & =9.86
\end{aligned}
$$

Notes: Source of government spending data is Fiscal Affairs Department of the IMF. Data are described in text. For the number of observations " $\mathrm{N}$ " refers to total observations in the pooled sample, " $\mathrm{n}$ " to the number of countries, and "T-bar" (= N/n) to the average number of observations per country. For measures of dispersion, "overall" refers to the pooled observation sample, "between" refers to country averages, and within refers to deviations from country averages plus overall mean. 
Table 2

Summary Statistics for Democracy Indices from Freedom House and Polity IV

\begin{tabular}{|c|c|c|c|c|c|c|}
\hline & & Mean & Std. Dev. & Min & Max & Observations \\
\hline \multirow{3}{*}{$\begin{array}{l}\text { PIV Institutionalized } \\
\text { Democracy score }\end{array}$} & overall & 0.458 & 0.420 & 0 & 1 & $N=1787$ \\
\hline & between & & 0.384 & 0 & 1 & $n=142$ \\
\hline & within & & 0.164 & -0.273 & 1.012 & $\mathrm{~T}$-bar $=12.58$ \\
\hline \multirow{3}{*}{$\begin{array}{l}\text { FH Political rights } \\
\text { score }\end{array}$} & overall & 0.528 & 0.364 & 0 & 1 & $N=1787$ \\
\hline & between & & 0.329 & 0 & 1 & $n=142$ \\
\hline & within & & 0.154 & 0.004 & 1.049 & $\mathrm{~T}$-bar $=12.58$ \\
\hline
\end{tabular}

Table 3

Transition probabilities (in \%) for PIV Institutionalized Democracy Score

\begin{tabular}{lrrrrrrrrrrr}
\hline & 0 & 0.1 & 0.2 & 0.3 & 0.4 & 0.5 & 0.6 & 0.7 & 0.8 & 0.9 & 1 \\
\hline 0 & 94 & 1 & 1 & 0 & 0 & 1 & 1 & 0 & 0 & 0 & 0 \\
0.1 & 6 & 86 & 3 & 3 & 0 & 0 & 1 & 0 & 0 & 1 & 0 \\
0.2 & 0 & 0 & 89 & 3 & 3 & 3 & 0 & 0 & 3 & 0 & 0 \\
0.3 & 10 & 3 & 0 & 72 & 3 & 0 & 3 & 7 & 0 & 0 & 0 \\
0.4 & 4 & 4 & 0 & 0 & 80 & 0 & 4 & 0 & 4 & 4 & 0 \\
0.5 & 0 & 0 & 0 & 0 & 2 & 87 & 4 & 2 & 6 & 0 & 0 \\
0.6 & 1 & 0 & 0 & 2 & 2 & 2 & 91 & 2 & 1 & 0 & 0 \\
0.7 & 0 & 0 & 0 & 0 & 0 & 0 & 3 & 89 & 6 & 1 & 0 \\
0.8 & 2 & 0 & 1 & 1 & 0 & 0 & 0 & 2 & 89 & 6 & 1 \\
0.9 & 1 & 0 & 0 & 0 & 0 & 0 & 0 & 1 & 4 & 92 & 2 \\
1 & 0 & 0 & 0 & 0 & 0 & 0 & 0 & 0 & 0 & 0 & 100 \\
\hline Total & 36.47 & 4.43 & 2.71 & 1.85 & 1.66 & 3.2 & 7.5 & 5.66 & 7.93 & 6.46 & 22.14 \\
\hline
\end{tabular}

Notes: Underlying data are pooled times-series cross-section for PIV measure of democracy for a sample of 142 countries. 1 represents highest rating for democracy. 
Table 4

Changes in Social Sector Spending by Episodes

of Changes in Democracy Index

\begin{tabular}{lrr}
\hline \hline $\begin{array}{l}\text { Change in } \\
\text { Democracy Index }\end{array}$ & $\begin{array}{c}\text { No. of } \\
\text { cases }\end{array}$ & $\begin{array}{r}\text { Median change in } \\
\text { spending (\% GDP) }\end{array}$ \\
\hline & & \\
$<-0.3$ & 2 & -0.13 \\
$<-0.2$ & 3 & 0.17 \\
$<-0.1$ & 4 & -0.69 \\
$<0$ & 10 & -0.06 \\
& & \\
$>0$ & 34 & 0.14 \\
$>0.1$ & 18 & 0.32 \\
$>0.2$ & 13 & 0.11 \\
$>0.3$ & 9 & 0.37 \\
\hline Notes: The table identifies episodes in which the Polity IV index of democracy changed \\
by the amount indicated in the first column. For the set of countries identified in each \\
such episode, it calculates the mean for heaith and education spending two yeas prior \\
to the change and for the two years after the change (for cases in which the democracy \\
index remained unchanged in two years prior and after). It then calculates the change \\
in the spending for each such episode, and the last column reports the median of these \\
changes.
\end{tabular}


Table 5

Regressions for Total Government Spending

\begin{tabular}{|c|c|c|c|c|}
\hline & (1) & (2) & (3) & (4) \\
\hline Model & Between & Between & FE & $\mathrm{FE}$ \\
\hline PIV democracy score & $\begin{array}{l}-1.882 \\
(2.894)\end{array}$ & $\begin{array}{l}-3.697 \\
(3.219)\end{array}$ & $\begin{array}{c}-3.323^{\star \star \star} \\
(0.774)\end{array}$ & $\begin{array}{l}-1.465^{*} \\
(0.855)\end{array}$ \\
\hline $\log (\operatorname{rgdp})$ & $\begin{array}{c}4.358^{* * *} \\
(1.030)\end{array}$ & $\begin{array}{c}0.171 \\
(1.814)\end{array}$ & $\begin{array}{c}-3.373^{\star * *} \\
(1.140)\end{array}$ & $\begin{array}{l}-0.766 \\
(1.435)\end{array}$ \\
\hline Log (population) & & $\begin{array}{l}-1.115 \\
(0.847)\end{array}$ & & $\begin{array}{l}-1.607 \\
(3.903)\end{array}$ \\
\hline Log (trade/GDP) & & $\begin{array}{l}5.583^{* *} \\
(2.396)\end{array}$ & & $\begin{array}{l}1.935^{* *} \\
(0.863)\end{array}$ \\
\hline$\%$ Population urbanized & & $\begin{array}{c}0.068 \\
(0.066)\end{array}$ & & $\begin{array}{c}0.082 \\
(0.074)\end{array}$ \\
\hline$\%$ Population aged $<15$ & & $\begin{array}{c}-0.630^{\star * *} \\
(0.179)\end{array}$ & & $\begin{array}{c}0.385^{* * *} \\
(0.130)\end{array}$ \\
\hline Illiteracy rate & & $\begin{array}{c}0.090 \\
(0.061)\end{array}$ & & $\begin{array}{l}0.267^{\star *} \\
(0.108)\end{array}$ \\
\hline Observations & 1347 & 1045 & 1347 & 1045 \\
\hline Number of countries & 117 & 90 & 117 & 90 \\
\hline
\end{tabular}


Table 6

Regressions for Education and Health Spending, Between Estimator

\begin{tabular}{|c|c|c|c|c|c|c|c|c|}
\hline PIV democracy score & $\begin{array}{r}-1.840 \\
(1.418)\end{array}$ & $\begin{array}{l}3.419^{\star \star \star} \\
(1.242)\end{array}$ & $\begin{array}{c}-0.572 \\
(0.448)\end{array}$ & $\begin{array}{c}1.264^{* * *} \\
(0.406)\end{array}$ & $\begin{array}{c}-0.625 \\
(1.788)\end{array}$ & $\begin{array}{c}0.887 \\
(1.337)\end{array}$ & $\begin{array}{c}-0.131 \\
(0.580)\end{array}$ & $\begin{array}{c}0.410 \\
(0.372)\end{array}$ \\
\hline $\log (\operatorname{rgdp})$ & $\begin{array}{c}-0.921^{*} \\
(0.540)\end{array}$ & $\begin{array}{c}0.366 \\
(0.471)\end{array}$ & $\begin{array}{c}-0.280 \\
(0.171)\end{array}$ & $\begin{array}{c}0.031 \\
(0.154)\end{array}$ & $\begin{array}{l}2.130^{\star *} \\
(1.026)\end{array}$ & $\begin{array}{c}0.311 \\
(0.779)\end{array}$ & $\begin{array}{l}0.676^{\star \star} \\
(0.333)\end{array}$ & $\begin{array}{c}-0.024 \\
(0.217)\end{array}$ \\
\hline Log (population) & & & & & $\begin{array}{c}0.320 \\
(0.497)\end{array}$ & $\begin{array}{l}-0.690^{\star} \\
(0.367)\end{array}$ & $\begin{array}{c}0.098 \\
(0.161)\end{array}$ & $\begin{array}{c}-0.156 \\
(0.102)\end{array}$ \\
\hline$\%$ Population aged $<15$ & & & & & $\begin{array}{c}0.410^{\star \star \star} \\
(0.099)\end{array}$ & $\begin{array}{c}0.085 \\
(0.075)\end{array}$ & $\begin{array}{c}0.148^{\star * *} \\
(0.032)\end{array}$ & $\begin{array}{c}0.015 \\
(0.021)\end{array}$ \\
\hline Illiteracy rate & & & & & $\begin{array}{r}-0.039 \\
(0.034)\end{array}$ & $\begin{array}{c}-0.036 \\
(0.026)\end{array}$ & $\begin{array}{c}-0.011 \\
(0.011)\end{array}$ & $\begin{array}{c}-0.010 \\
(0.007)\end{array}$ \\
\hline Defense exp. (\% GDP) & & & & & $\begin{array}{c}-0.649^{* * *} \\
(0.204)\end{array}$ & $\begin{array}{c}-0.442^{\star \star \star} \\
(0.158)\end{array}$ & $\begin{array}{c}-0.228^{* * *} \\
(0.066)\end{array}$ & $\begin{array}{c}-0.142^{* \star *} \\
(0.044)\end{array}$ \\
\hline Countries & 106 & 106 & 106 & 106 & 78 & 78 & 78 & 78 \\
\hline
\end{tabular}

Notes: Regressions are for education and health and spending (as \% of total government spending and as \% of GDP). Number of observations falls because of availability of data for the control variables. Standard errors are in parentheses. ${ }^{*}$ denotes significance at $10 \%,{ }^{* *}$ at $5 \%$, and ${ }^{* \star \star}$ at $1 \%$. 
Table 7

Regressions for Education and Health Spending, Fixed Effects

\begin{tabular}{|c|c|c|c|c|c|c|c|c|}
\hline & $\begin{array}{c}\text { (1) } \\
\text { Education, } \\
\% \text { total exp }\end{array}$ & $\begin{array}{c}\text { (2) } \\
\text { Health, } \\
\% \text { total exp. }\end{array}$ & $\begin{array}{c}\text { (3) } \\
\text { Education, } \\
\% \text { GDP } \\
\end{array}$ & $\begin{array}{c}\text { (4) } \\
\text { Health, } \\
\% \text { GDP }\end{array}$ & $\begin{array}{c}\text { (5) } \\
\text { Education, } \\
\% \text { total exp. }\end{array}$ & $\begin{array}{c}\text { (6) } \\
\text { Health, } \\
\% \text { total exp. }\end{array}$ & $\begin{array}{c}\text { (7) } \\
\text { Education, } \\
\% \text { GDP }\end{array}$ & $\begin{array}{c}(8) \\
\text { Health, } \\
\% \text { GDP }\end{array}$ \\
\hline PIV democracy score & $\begin{array}{l}1.963^{\star * \star} \\
(0.409)\end{array}$ & $\begin{array}{l}1.910^{\star \star \star} \\
(0.299)\end{array}$ & $\begin{array}{l}0.319^{\star \star *} \\
(0.118)\end{array}$ & $\begin{array}{l}0.318^{* *} \\
(0.084)\end{array}$ & $\begin{array}{l}1.085^{\star *} \\
(0.481)\end{array}$ & $\begin{array}{c}1.390^{\star * \star} \\
(0.337)\end{array}$ & $\begin{array}{c}0.083 \\
(0.137)\end{array}$ & $\begin{array}{l}0.170^{* *} \\
(0.086)\end{array}$ \\
\hline Govt. Exp (\% GDP) & $\begin{array}{c}-0.146^{\star \star \star} \\
(0.017)\end{array}$ & $\begin{array}{c}-0.135^{\star \star \star} \\
(0.012)\end{array}$ & $\begin{array}{l}0.070^{\star \star \star} \\
(0.005)\end{array}$ & $\begin{array}{l}0.020^{\star \star \star} \\
(0.003)\end{array}$ & $\begin{array}{c}-0.164^{\star \star \star} \\
(0.023)\end{array}$ & $\begin{array}{c}-0.125^{\star * *} \\
(0.016)\end{array}$ & $\begin{array}{l}0.077^{\star \star \star} \\
(0.006)\end{array}$ & $\begin{array}{c}0.029^{\star \star \star} \\
(0.004)\end{array}$ \\
\hline $\log (\operatorname{rgdp})$ & $\begin{array}{l}3.819^{* * *} \\
(0.653)\end{array}$ & $\begin{array}{l}1.798^{\star \star \star} \\
(0.468)\end{array}$ & $\begin{array}{l}1.000^{* * *} \\
(0.188)\end{array}$ & $\begin{array}{c}0.359^{* * *} \\
(0.131)\end{array}$ & $\begin{array}{c}3.183^{\star \star \star} \\
(0.913)\end{array}$ & $\begin{array}{c}0.451 \\
(0.634)\end{array}$ & $\begin{array}{c}0.772^{\star * \star} \\
(0.259)\end{array}$ & $\begin{array}{c}0.177 \\
\langle 0.162\rangle\end{array}$ \\
\hline Log (population) & & & & & $\begin{array}{c}10.657^{\star \star \star} \\
(2.302)\end{array}$ & $\begin{array}{l}9.126^{* \star *} \\
(1.622)\end{array}$ & $\begin{array}{l}1.927^{\star \star \star} \\
(0.654)\end{array}$ & $\begin{array}{l}1.682^{\star * *} \\
(0.415)\end{array}$ \\
\hline $\log ($ trade/GDP) & & & & & $\begin{array}{c}-1.403^{* *} \\
(0.581)\end{array}$ & $\begin{array}{c}-0.166 \\
(0.379)\end{array}$ & $\begin{array}{c}-0.815^{\star * *} \\
(0.165)\end{array}$ & $\begin{array}{c}-0.213^{* *} \\
(0.097)\end{array}$ \\
\hline$\%$ Population urbanized & & & & & $\begin{array}{c}0.128^{\star * *} \\
(0.042)\end{array}$ & $\begin{array}{c}-0.009 \\
(0.029)\end{array}$ & $\begin{array}{c}0.060^{\star \star \star} \\
(0.012)\end{array}$ & $\begin{array}{c}-0.006 \\
(0.007)\end{array}$ \\
\hline$\%$ Population aged < 15 & & & & & $\begin{array}{c}-0.042 \\
(0.083)\end{array}$ & $\begin{array}{r}-0.015 \\
(0.059)\end{array}$ & $\begin{array}{c}-0.015 \\
(0.024)\end{array}$ & $\begin{array}{l}0.030^{\star *} \\
(0.015)\end{array}$ \\
\hline Illiteracy rate & & & & & $\begin{array}{c}0.267^{* * *} \\
(0.075)\end{array}$ & $\begin{array}{l}0.163^{\star * \star} \\
(0.054)\end{array}$ & $\begin{array}{l}0.055^{\star \star} \\
(0.021)\end{array}$ & $\begin{array}{c}0.004 \\
(0.014)\end{array}$ \\
\hline Defense exp. ( $\%$ GDP $)$ & & & & & $\begin{array}{c}0.056 \\
(0.064)\end{array}$ & $\begin{array}{c}0.027 \\
(0.045)\end{array}$ & $\begin{array}{l}-0.031^{\star} \\
(0.018)\end{array}$ & $\begin{array}{l}-0.020^{\star} \\
(0.012)\end{array}$ \\
\hline Observations & 1061 & 1048 & 1061 & 1048 & 737 & 724 & 737 & 724 \\
\hline Countries & 106 & 106 & 106 & 106 & 78 & 78 & 78 & 78 \\
\hline
\end{tabular}

Notes: Regressions are for education and health and spending (as \% of total government spending and as \% of GDP). Number of observations falls because of availability of data. Standard errors in parentheses. "denotes significance at $10 \%$, ** at $5 \%$, and ${ }^{* * *}$ at $1 \%$. 
Table 8

Regressions for Education and Health Spending, Fixed Effects using Central Government FAD Data

\begin{tabular}{|c|c|c|c|c|c|c|c|c|}
\hline & $\begin{array}{c}\text { (1) } \\
\text { Education, } \\
\% \text { total exp }\end{array}$ & $\begin{array}{c}\text { (2) } \\
\text { Health, } \\
\% \text { total exp. }\end{array}$ & $\begin{array}{l}\quad(3) \\
\text { Education, } \\
\% \text { GDP }\end{array}$ & $\begin{array}{c}(4) \\
\text { Health, } \\
\% \text { GDP }\end{array}$ & $\begin{array}{c}\text { (5) } \\
\text { Education, } \\
\% \text { total exp. }\end{array}$ & $\begin{array}{c}(6) \\
\text { Health, } \\
\% \text { total exp. }\end{array}$ & $\begin{array}{l}\quad(7) \\
\text { Education, } \\
\% \text { GDP }\end{array}$ & $\begin{array}{c}\text { (8) } \\
\text { Health, } \\
\% \text { GDP }\end{array}$ \\
\hline PIV democracy score & $\begin{array}{c}2.464^{\star \star \star *} \\
(0.496)\end{array}$ & $\begin{array}{c}2.385^{\star \star \star} \\
(0.306)\end{array}$ & $\begin{array}{c}0.497^{\star \star \star} \\
(0.132)\end{array}$ & $\begin{array}{c}0.390^{* * *} \\
(0.069)\end{array}$ & $\begin{array}{l}1.636^{\star \pm \pm} \\
(0.550)\end{array}$ & $\begin{array}{l}1.740^{* * *} \\
(0.349)\end{array}$ & $\begin{array}{l}0.287^{* *} \\
(0.144)\end{array}$ & $\begin{array}{c}0.180^{* *} \\
(0.076)\end{array}$ \\
\hline Govt. $\operatorname{Exp}(\%$ GDP) & $\begin{array}{c}-0.159^{\star * *} \\
(0.027)\end{array}$ & $\begin{array}{c}-0.146^{\star \star \star} \\
(0.017)\end{array}$ & $\begin{array}{c}0.083^{\star \star \star} \\
(0.007)\end{array}$ & $\begin{array}{c}0.019^{\star \star \star} \\
(0.004)\end{array}$ & $\begin{array}{c}-0.167^{\star * \star} \\
(0.031)\end{array}$ & $\begin{array}{c}-0.151^{* * *} \\
(0.021)\end{array}$ & $\begin{array}{c}0.087^{* * *} \\
(0.008)\end{array}$ & $\begin{array}{c}0.025^{\star * *} \\
(0.005)\end{array}$ \\
\hline $\log (\operatorname{rgd} p)$ & $\begin{array}{c}2.547^{\star \star \star} \\
(0.880)\end{array}$ & $\begin{array}{c}0.822 \\
(0.543)\end{array}$ & $\begin{array}{c}0.645^{* * *} \\
(0.235)\end{array}$ & $\begin{array}{c}0.229^{*} \\
(0.122)\end{array}$ & $\begin{array}{c}1.178 \\
(1.129)\end{array}$ & $\begin{array}{c}-0.573 \\
(0.727)\end{array}$ & $\begin{array}{c}0.152 \\
(0.296)\end{array}$ & $\begin{array}{c}0.058 \\
(0.159)\end{array}$ \\
\hline Log (population) & & & & & $\begin{array}{c}11.964^{\star \star \star} \\
(3.055)\end{array}$ & $\begin{array}{l}9.727^{\star \star \star} \\
(2.028)\end{array}$ & $\begin{array}{c}2.303^{* * *} \\
(0.801)\end{array}$ & $\begin{array}{c}2.090^{\star \star \star} \\
(0.444)\end{array}$ \\
\hline $\log ($ trade/GDP) & & & & & $\begin{array}{c}-1.035 \\
(0.695)\end{array}$ & $\begin{array}{c}-0.219 \\
(0.459)\end{array}$ & $\begin{array}{c}-0.728^{\star \star *} \\
(0.182)\end{array}$ & $\begin{array}{c}-0.139 \\
(0.100)\end{array}$ \\
\hline$\%$ Population urbanized & & & & & $\begin{array}{c}0.134^{\star \star \star} \\
(0.046)\end{array}$ & $\begin{array}{c}-0.030 \\
(0.029)\end{array}$ & $\begin{array}{c}0.061^{\star \star \star} \\
(0.012)\end{array}$ & $\begin{array}{c}-0.009 \\
(0.006)\end{array}$ \\
\hline$\%$ Population aged $<15$ & & & & & $\begin{array}{c}-0.165 \\
(0.103)\end{array}$ & $\begin{array}{c}-0.187^{* * *} \\
(0.067)\end{array}$ & $\begin{array}{c}-0.055^{\star *} \\
(0.027)\end{array}$ & $\begin{array}{c}-0.014 \\
(0.015)\end{array}$ \\
\hline Iliteracy rate & & & & & $\begin{array}{c}0.367^{\star \star \star} \\
(0.089)\end{array}$ & $\begin{array}{c}0.203^{\star \star \star} \\
(0.060)\end{array}$ & $\begin{array}{c}0.080^{\star \star *} \\
(0.023)\end{array}$ & $\begin{array}{c}0.022 \\
(0.013)\end{array}$ \\
\hline Defense exp. (\% GDP) & & & & & $\begin{array}{c}0.119 \\
(0.079)\end{array}$ & $\begin{array}{c}0.050 \\
(0.050)\end{array}$ & $\begin{array}{c}-0.001 \\
(0.021)\end{array}$ & $\begin{array}{c}0.002 \\
(0.011)\end{array}$ \\
\hline Observations & 687 & 666 & 687 & 666 & 574 & 553 & 574 & 553 \\
\hline Countries & 67 & 67 & 67 & 67 & 59 & 59 & 59 & 59 \\
\hline
\end{tabular}

Notes: Regressions are for education and health and spending (as \% of total government spending and as \% of GDP). Number of observations falls because of availability of data. Standard errors are in parentheses. "denotes significance at $10 \%,{ }^{* *}$ at $5 \%$, and ${ }^{* * *}$ at $1 \%$. 
Table 9

Sensitivity of Estimated Coefficients on Democracy and Government Spending to Influential Observations

\begin{tabular}{|c|c|c|c|c|c|}
\hline \multirow[b]{2}{*}{ Dependent variable } & \multirow[b]{2}{*}{ Sample } & \multicolumn{2}{|c|}{ PIV Democray score } & \multicolumn{2}{|c|}{ Govt. Exp (\% GDP) } \\
\hline & & Coefficient & Stand. Error & Coefficient & Stand. Error \\
\hline $\begin{array}{l}\text { Education, } \\
\% \text { total govt. exp. }\end{array}$ & $\begin{array}{l}\text { FAD, Central Govt. } \\
\text { Excluding Gambia } \\
\text { Excluding outliers based on DFBetas }\end{array}$ & $\begin{array}{l}1.636^{\star \star \star} \\
2.717^{\star \star \star} \\
2.649^{\star \star \star}\end{array}$ & $\begin{array}{l}(0.550) \\
(0.546) \\
(0.632)\end{array}$ & $\begin{array}{l}-0.167^{\star \star *} \\
-0.165^{\star * *} \\
-0.182^{\star * *}\end{array}$ & $\begin{array}{l}(0.031) \\
(0.029) \\
(0.030)\end{array}$ \\
\hline $\begin{array}{l}\text { Health, } \\
\% \text { total govt. exp. }\end{array}$ & $\begin{array}{l}\text { FAD, Central Govt. } \\
\text { Excluding Gambia } \\
\text { Excluding outliers based on DFBetas }\end{array}$ & $\begin{array}{l}1.740^{* * *} \\
2.074^{* \star \star} \\
1.742^{* * *}\end{array}$ & $\begin{array}{l}(0.349) \\
(0.364) \\
(0.383)\end{array}$ & $\begin{array}{l}-0.151^{* * *} \\
-0.150^{\star \star \star} \\
-0.105^{\star * *}\end{array}$ & $\begin{array}{l}(0.021) \\
(0.021) \\
(0.019)\end{array}$ \\
\hline $\begin{array}{l}\text { Education, } \\
\% \text { GDP }\end{array}$ & $\begin{array}{l}\text { FAD, Central Govt. } \\
\text { Excluding Gambia } \\
\text { Excluding outliers based on DFBetas }\end{array}$ & $\begin{array}{l}0.287^{* *} \\
0.568^{* * *} \\
0.551^{* * *}\end{array}$ & $\begin{array}{l}(0.144) \\
(0.142) \\
(0.154)\end{array}$ & $\begin{array}{l}0.087^{\star \star \star \star} \\
0.088^{\star \star \star} \\
0.084^{\star \star \star}\end{array}$ & $\begin{array}{l}(0.008) \\
(0.008) \\
(0.008)\end{array}$ \\
\hline $\begin{array}{l}\text { Heath, } \\
\% \text { GDP }\end{array}$ & $\begin{array}{l}\text { FAD, Central Govt. } \\
\text { Excluding Gambia } \\
\text { Excluding outliers based on DFBetas }\end{array}$ & $\begin{array}{l}0.180^{\star \star} \\
0.240^{\star \star *} \\
0.214^{\star \star}\end{array}$ & $\begin{array}{l}(0.076) \\
(0.079) \\
(0.087)\end{array}$ & $\begin{array}{l}0.025^{\star * *} \\
0.026^{* * *} \\
0.026^{* * *}\end{array}$ & $\begin{array}{l}(0.005) \\
(0.005) \\
(0.005)\end{array}$ \\
\hline $\begin{array}{l}\text { Education + Health, } \\
\% \text { total govt. exp. }\end{array}$ & $\begin{array}{l}\text { FAD, Central Govt. } \\
\text { Excluding Gambia } \\
\text { Excluding outliers based on DFBetas }\end{array}$ & $\begin{array}{l}3.245^{\star * *} \\
4.713^{\star * *} \\
4.683^{* * *}\end{array}$ & $\begin{array}{l}(0.768) \\
(0.766) \\
(0.903)\end{array}$ & $\begin{array}{l}-0.318^{* * *} \\
-0.318^{\star * *} \\
-0.314^{* \star \star}\end{array}$ & $\begin{array}{l}(0.046) \\
(0.044) \\
(0.049)\end{array}$ \\
\hline $\begin{array}{l}\text { Education + Health } \\
\% \text { GDP }\end{array}$ & $\begin{array}{l}\text { FAD, Central Govt. } \\
\text { Excluding Gambia } \\
\text { Excluding outliers based on DFBetas }\end{array}$ & $\begin{array}{l}0.427^{* *} \\
0.783^{* * *} \\
0.687^{* *}\end{array}$ & $\begin{array}{l}(0.187) \\
(0.185) \\
(0.201)\end{array}$ & $\begin{array}{l}0.115^{\star * *} \\
0.115^{\star \star \star} \\
0.120^{\star \star \star}\end{array}$ & $\begin{array}{l}(0.011) \\
(0.011) \\
(0.010)\end{array}$ \\
\hline
\end{tabular}

Notes: FAD, Central Govt. sample is all observations for which the government spending data comes from the FAD dataset and refers to the central government. Each coefficient is taken from a different regression. The number of observations varies from 505 to 574 depending on the number of observations exciuded. The third row for each dependent varible reports the estimated coefficient when those observations are excluded for which the absolute value of the DFBeta $x$ square root of the number of observations exceeds 2, as suggested in Belsley et. al. (1980). ${ }^{* \star}$ denotes significance at $1 \%{ }^{* *}$ at $5 \%$ and ${ }^{*}$ at $10 \%$. 
Table 10

Regressions for Social Sector Spending, Freedom House Measure of Democracy

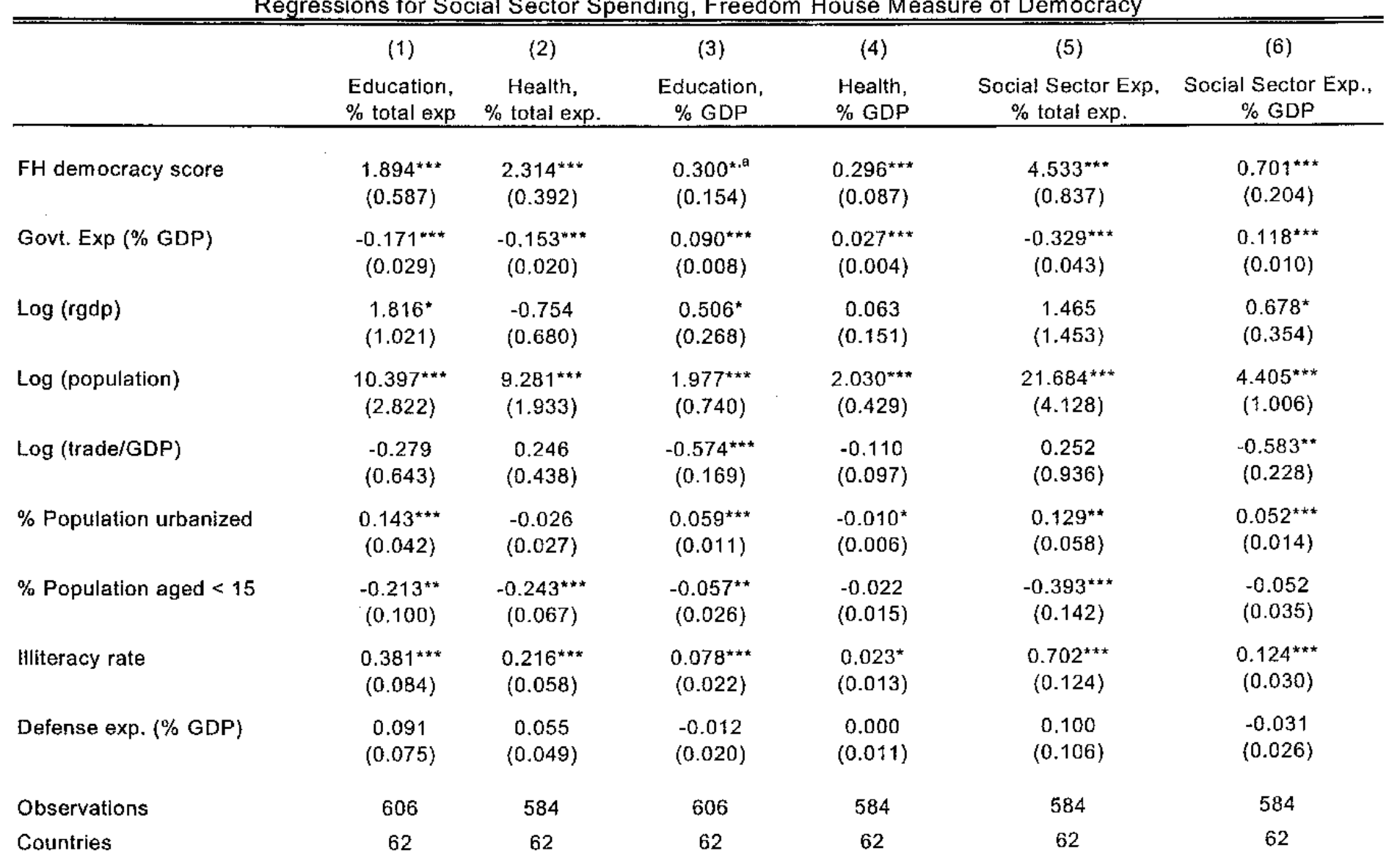

Notes: Fixed effects estimation using FAD Central Government Data. "Social Sector Exp" refers to education + health expenditure. FH Democracy score is the Freedom House/ Gastil measure of political rights which has been converted to a $0-1$ scale with 1corresponding to the highest rating for political rights. Data excludes Gambia as discussed in text. Standard errors are in parentheses. ${ }^{*}$ denotes significance at $10 \%,{ }^{* *}$ at $5 \%$, and ${ }^{* * *}$ at $1 \%$. a p-value $=0.052$. 
Table 11

Regressions for Social Sector Spending, Period Averages and Allowing for Correlation within Countries

\begin{tabular}{|c|c|c|c|c|c|c|}
\hline \multirow{2}{*}{$\begin{array}{l}\text { Model } \\
\text { Dependent variable }\end{array}$} & \multicolumn{2}{|c|}{ 5-year averages } & \multicolumn{2}{|c|}{ Democracy period averages } & \multicolumn{2}{|c|}{ Correlated etrors within country groups } \\
\hline & $\begin{array}{c}\text { Soc. Sec. Exp., } \\
\% \text { total exp. }\end{array}$ & $\begin{array}{c}\text { Soc. Sec. Exp., } \\
\% \text { GDP }\end{array}$ & $\begin{array}{c}\text { Soc. Sec. Exp., } \\
\% \text { total exp. }\end{array}$ & $\begin{array}{c}\text { Soc. Sec. Exp., } \\
\% \text { GDP }\end{array}$ & $\begin{array}{c}\text { Soc. Sec. Exp., } \\
\% \text { tota! exp. }\end{array}$ & $\begin{array}{c}\text { Soc. Sec. Exp. } \\
\% \text { GDP } \\
\end{array}$ \\
\hline PIV democracy score & $\begin{array}{l}6.989^{\star * *} \\
(1.800)\end{array}$ & $\begin{array}{l}1.273^{* * *} \\
(0.473)\end{array}$ & $\begin{array}{l}4.678^{\star *} \\
(2.025)\end{array}$ & $\begin{array}{l}1.300^{* *} \\
(0.606)\end{array}$ & $\begin{array}{l}4.713^{\star \star \star} \\
(1.629)\end{array}$ & $\begin{array}{l}0.783^{* *} \\
(0.387)\end{array}$ \\
\hline Govt. Exp (\% GDP) & $\begin{array}{l}-0.307^{* * *} \\
(0.093)\end{array}$ & $\begin{array}{l}0.094^{\star \star *} \\
(0.025)\end{array}$ & $\begin{array}{l}-0.385^{* *} \\
(0.187)\end{array}$ & $\begin{array}{c}0.084 \\
(0.056)\end{array}$ & $\begin{array}{c}-0.318^{\star \star \star} \\
(0.094)\end{array}$ & $\begin{array}{l}0.115^{* * *} \\
(0.027)\end{array}$ \\
\hline $\log (r g d p)$ & $\begin{array}{c}1.466 \\
(3.109)\end{array}$ & $\begin{array}{c}0.469 \\
(0.818)\end{array}$ & $\begin{array}{l}-\{.746 \\
(4.644)\end{array}$ & $\begin{array}{l}-0.941 \\
(1.390)\end{array}$ & $\begin{array}{c}0.839 \\
(2.244)\end{array}$ & $\begin{array}{c}0.298 \\
(0.648)\end{array}$ \\
\hline Log (population) & $\begin{array}{l}16.668^{* *} \\
(7.450)\end{array}$ & $\begin{array}{c}3.238 \\
(1.959)\end{array}$ & $\begin{array}{l}23.771^{*} \\
(13.823)\end{array}$ & $\begin{array}{c}0.398 \\
(4.138)\end{array}$ & $\begin{array}{l}20.362^{* *} \\
(8.855)\end{array}$ & $\begin{array}{l}3.966^{\star *} \\
(1.746)\end{array}$ \\
\hline $\log ($ trade/GDP) & $\begin{array}{l}-1.439 \\
(2.263)\end{array}$ & $\begin{array}{l}-0.728 \\
(0.595)\end{array}$ & $\begin{array}{c}2.039 \\
(3.706)\end{array}$ & $\begin{array}{c}0.608 \\
(1.109)\end{array}$ & $\begin{array}{l}-0.582 \\
(2.183)\end{array}$ & $\begin{array}{l}-0.668 \\
(0.469)\end{array}$ \\
\hline$\%$ Population urbanized & $\begin{array}{c}0.138 \\
(0.111)\end{array}$ & $\begin{array}{l}0.061^{* *} \\
(0.029)\end{array}$ & $\begin{array}{c}0.294 \\
\{0.286\}\end{array}$ & $\begin{array}{c}0.081 \\
(0.086)\end{array}$ & $\begin{array}{c}0.141 \\
(0.106)\end{array}$ & $\begin{array}{l}0.061^{* *} \\
(0.027)\end{array}$ \\
\hline$\%$ Population aged $<15$ & $\begin{array}{l}-0.302 \\
(0.237)\end{array}$ & $\begin{array}{l}-0.058 \\
(0.062)\end{array}$ & $\begin{array}{l}-0.367 \\
(0.345)\end{array}$ & $\begin{array}{l}-0.104 \\
(0.103)\end{array}$ & $\begin{array}{l}-0.328 \\
\langle 0.269\}\end{array}$ & $\begin{array}{l}-0.050 \\
(0.063)\end{array}$ \\
\hline Illiteracy rate & $\begin{array}{l}0.561^{\star \star \star} \\
(0.201)\end{array}$ & $\begin{array}{l}0.120^{\star \star} \\
(0.053)\end{array}$ & $\begin{array}{l}0.826^{* *} \\
(0.340)\end{array}$ & $\begin{array}{c}0.127 \\
(0.102)\end{array}$ & $\begin{array}{l}0.698^{* k} \\
(0.292)\end{array}$ & $\begin{array}{l}0.131^{* *} \\
(0.055)\end{array}$ \\
\hline Defense exp. (\% GDP) & $\begin{array}{c}0.095 \\
(0.233)\end{array}$ & $\begin{array}{l}-0.040 \\
(0.061)\end{array}$ & $\begin{array}{c}0.628 \\
(0.510)\end{array}$ & $\begin{array}{c}-0.148 \\
(0.153)\end{array}$ & $\begin{array}{c}0.058 \\
(0.140)\end{array}$ & $\begin{array}{c}-0.037 \\
(0.040)\end{array}$ \\
\hline Observations & 129 & 129 & 107 & 107 & 546 & 546 \\
\hline Countries & 52 & 52 & 59 & 59 & 58 & 58 \\
\hline
\end{tabular}


Table 12

IV Estimation for Social Sector Spending

\begin{tabular}{|c|c|c|c|c|c|}
\hline & \multirow{2}{*}{$\begin{array}{l}\text { PIV Democracy } \\
\text { Score }\end{array}$} & \multicolumn{2}{|c|}{ Social Sector Exp., \% Total Exp. } & \multicolumn{2}{|c|}{ Social Sector Exp., \% GDP } \\
\hline & & OLS & 2SLS & OLS & 2SLS \\
\hline PIV democracy score & & $\begin{array}{l}4.713^{\star \star \star} \\
(0.766)\end{array}$ & $\begin{array}{c}6.669^{*} \\
(3.491)\end{array}$ & $\begin{array}{l}0.783^{\star * *} \\
(0.185)\end{array}$ & $\begin{array}{c}1.477^{\star} \\
(0.850)\end{array}$ \\
\hline $\log (\operatorname{rgd} p)$ & $\begin{array}{l}0.429^{* * *} \\
(0.089)\end{array}$ & $\begin{array}{c}0.839 \\
(1.524)\end{array}$ & & $\begin{array}{c}0.298 \\
(0.368)\end{array}$ & \\
\hline Govt. $\operatorname{Exp}(\%$ GDP) & $\begin{array}{c}0.003 \\
(0.003)\end{array}$ & $\begin{array}{c}-0.318^{\star * *} \\
(0.044)\end{array}$ & $\begin{array}{c}-0.325^{\star \star \star} \\
(0.045\rangle\end{array}$ & $\begin{array}{c}0.115^{* * *} \\
(0.011)\end{array}$ & $\begin{array}{c}0.113^{\star \star \star} \\
(0.011)\end{array}$ \\
\hline Log (population) & $\begin{array}{l}1.488^{* * *} \\
(0.246)\end{array}$ & $\begin{array}{c}20.362^{\star \star *} \\
(4.284)\end{array}$ & $\begin{array}{c}17.451^{* * *} \\
(6.424)\end{array}$ & $\begin{array}{c}3.966^{\star * *} \\
(1.034)\end{array}$ & $\begin{array}{l}2.934^{*} \\
(1.563)\end{array}$ \\
\hline Log (trade/GDP) & $\begin{array}{c}0.028 \\
(0.057)\end{array}$ & $\begin{array}{c}-0.582 \\
(0.966)\end{array}$ & $\begin{array}{c}-0.637 \\
(0.997)\end{array}$ & $\begin{array}{c}-0.668^{* * *} \\
(0.233)\end{array}$ & $\begin{array}{c}-0.687^{\star \star \star} \\
(0.243)\end{array}$ \\
\hline$\%$ Population urbanized & $\begin{array}{c}-0.005 \\
(0.004)\end{array}$ & $\begin{array}{l}0.141^{\text {** }} \\
(0.060)\end{array}$ & $\begin{array}{l}0.150^{* *} \\
(0.060)\end{array}$ & $\begin{array}{c}0.061^{* * *} \\
(0.015)\end{array}$ & $\begin{array}{l}0.065^{* * *} \\
(0.015)\end{array}$ \\
\hline$\%$ Population aged $<15$ & $\begin{array}{l}0.03\}^{* * *} \\
(0.008)\end{array}$ & $\begin{array}{c}-0.328^{\star *} \\
(0.141)\end{array}$ & $\begin{array}{c}-0.389^{* \star *} \\
(0.125)\end{array}$ & $\begin{array}{l}-0.050 \\
(0.034)\end{array}$ & $\begin{array}{c}-0.072^{* *} \\
(0.030)\end{array}$ \\
\hline Illiteracy rate & $\begin{array}{c}0.004 \\
(0.008)\end{array}$ & $\begin{array}{c}0.698^{* * *} \\
(0.126)\end{array}$ & $\begin{array}{c}0.690^{* * *} \\
(0.129)\end{array}$ & $\begin{array}{c}0.131^{\star \star \star} \\
(0.030)\end{array}$ & $\begin{array}{c}0.128^{\star \star \star} \\
(0.032)\end{array}$ \\
\hline Defense exp. (\% GDP) & $\begin{array}{l}-0.007 \\
(0.006)\end{array}$ & $\begin{array}{c}0.058 \\
(0.106)\end{array}$ & $\begin{array}{c}0.072 \\
(0.108)\end{array}$ & $\begin{array}{c}-0.037 \\
(0.026)\end{array}$ & $\begin{array}{c}-0.032 \\
(0.026)\end{array}$ \\
\hline Observations & 546 & 546 & 546 & 546 & 546 \\
\hline Countries & 58 & 58 & 58 & 58 & 58 \\
\hline
\end{tabular}

Notes: The first column reports the first-stage fixed effects regression for Polity IV democracy score (on $0-1$ scale with 1 representing the highest rating for democracy) on all RHS variables. The remaining four columns report the OLS and 2 SLS within estimates for social sector (education + health) spending, measured alternatively as the share in total government expenditure and GDP. Instrument for the democracy score is log(real GDP per capita). OLS within estimates without $\log (r e a l$ GDP per capita) are very similar to the regressions reported above. Sample conists of all observations from the FAD data set for the central government level. Standard errors in parenthesis. "denotes significance at $10 \%,{ }^{* *}$ at $5 \%$, and ${ }^{* * *}$ at $1 \%$. 
Table 13

First Differences Estimation for Social Sector Spending

\begin{tabular}{|c|c|c|c|c|c|c|}
\hline & \multicolumn{3}{|c|}{$\begin{array}{l}\text { Social Sector Expenditure, } \\
\% \text { Total Exp., First Difference }\end{array}$} & \multicolumn{3}{|c|}{$\begin{array}{l}\text { Social Sector Expenditure, } \\
\% \text { GDP, First Difference }\end{array}$} \\
\hline & (1) & (2) & (3) & (4) & (5) & (6) \\
\hline $\begin{array}{l}\text { Govt. Exp (\% GDP), } \\
\text { First Difference }\end{array}$ & $\begin{array}{c}-0.293^{* * *} \\
(0.031)\end{array}$ & $\begin{array}{l}-0.297^{* * *} \\
(0.032)\end{array}$ & $\begin{array}{c}-0.285^{* \star \star} \\
(0.031)\end{array}$ & $\begin{array}{l}0.095^{* * *} \\
(0.007)\end{array}$ & $\begin{array}{l}0.094^{* \star *} \\
(0.008)\end{array}$ & $\begin{array}{l}0.097^{* * *} \\
(0.008)\end{array}$ \\
\hline $\begin{array}{l}\log (\operatorname{rgdp}) \\
\text { First Difference }\end{array}$ & $\begin{array}{l}-0.451 \\
(2.015)\end{array}$ & $\begin{array}{l}-1.205 \\
(2.096)\end{array}$ & $\begin{array}{l}-0.443 \\
(2.069)\end{array}$ & $\begin{array}{l}-0.112 \\
(0.492)\end{array}$ & $\begin{array}{l}-0.337 \\
(0.520)\end{array}$ & $\begin{array}{l}-0.141 \\
(0.503)\end{array}$ \\
\hline $\begin{array}{l}\text { PIV Democracy score } \\
\text { First Difference }\end{array}$ & $\begin{array}{c}1.296 \\
(0.941)\end{array}$ & & & $\begin{array}{c}0.234 \\
(0.230)\end{array}$ & & \\
\hline $\begin{array}{l}\text { PIV Democracy score } \\
\text { Lagged first difference }\end{array}$ & & $\begin{array}{l}2.331^{\star \star} \\
(0.956)\end{array}$ & & & $\begin{array}{l}0.481^{\star \star} \\
(0.237)\end{array}$ & \\
\hline $\begin{array}{l}\text { PIV Democracy score } \\
\text { Leading first difference }\end{array}$ & & & $\begin{array}{l}-0.154 \\
(1.043)\end{array}$ & & & $\begin{array}{r}-0.059 \\
(0.254)\end{array}$ \\
\hline Observations & 582 & 547 & 550 & 582 & 547 & 550 \\
\hline
\end{tabular}


Table 14

Relationship between Democracy and Decentralization Indices

\begin{tabular}{|c|c|c|c|}
\hline $\begin{array}{l}\text { Measure of } \\
\text { decentralization }\end{array}$ & $\begin{array}{c}\text { Number of } \\
\text { observations }\end{array}$ & $\begin{array}{c}\text { Mean PIV } \\
\text { Democracy Score }\end{array}$ & $\begin{array}{c}\text { Mean FH Political } \\
\text { Rights Score }\end{array}$ \\
\hline \multicolumn{4}{|l|}{ Author } \\
\hline 0 & 272 & 0.312 & 0.436 \\
\hline 1 & 240 & 0.715 & 0.781 \\
\hline \multicolumn{4}{|l|}{ State } \\
\hline 0 & 397 & 0.311 & 0.454 \\
\hline 1 & 304 & 0.458 & 0.529 \\
\hline 2 & 288 & 0.706 & 0.736 \\
\hline \multicolumn{4}{|l|}{ Muni } \\
\hline 0 & 144 & 0.171 & 0.330 \\
\hline 1 & 144 & 0.344 & 0.453 \\
\hline 2 & 386 & 0.630 & 0.686 \\
\hline \multicolumn{4}{|c|}{$\begin{array}{l}\text { Notes: Decentralization variables are from Beck et. al. (1999)'s Database of Political Institutions } \\
\text { (DPI). Author }=1 \text { if sub-national governments have extensive taxing, spending or regulatory } \\
\text { authority, } 0 \text { otherwise; State }=0 \text { if neither the executive nor the legislature in the state government } \\
\text { is elected by the state population, = } 1 \text { if either is directly elected and the other is indirectly elected or } \\
\text { appointed, = } 2 \text { if both are directly elected by the state population. Muni is the analogous measure } \\
\text { for municipal governments in the country. If there are multiple levels of sub-national governments } \\
\text { the lowest level is considered "municipal." Observations are pooled time series cross section. PIV } \\
\text { is the Polity } N \text { democracy score and FH is the Freedom House score, both on } 0 \text { - } 1 \text { scale with } 1 \\
\text { representing the highest level of democracy. }\end{array}$} \\
\hline
\end{tabular}


Table 15

Between Regressions for General Government Expenditure on Social Sectors

\begin{tabular}{|c|c|c|c|c|}
\hline & \multicolumn{2}{|c|}{ Soc. Sec. Exp., \% Total Exp. } & \multicolumn{2}{|c|}{ Soc. Sec. Exp., \% GDP } \\
\hline & (1) & $(2)$ & (3) & (4) \\
\hline PIV democracy score & $\begin{array}{c}10.346^{* *} \\
(4.423)\end{array}$ & $\begin{array}{l}7.062^{\star \star} \\
(2.785)\end{array}$ & $\begin{array}{l}4.532^{* *} \\
(1.588)\end{array}$ & $\begin{array}{c}3.069^{*, a} \\
(1.406)\end{array}$ \\
\hline Govt. Exp (\% GDP) & $\begin{array}{c}-0.092 \\
(0.138)\end{array}$ & $\begin{array}{c}0.052 \\
(0.093)\end{array}$ & $\begin{array}{l}0.139^{\star *} \\
(0.050)\end{array}$ & $\begin{array}{c}0.210^{* \star *} \\
(0.047)\end{array}$ \\
\hline $\log ($ rgdp) & $\begin{array}{c}0.722 \\
(1.595)\end{array}$ & $\begin{array}{l}-2.620^{*} \\
(1.184)\end{array}$ & $\begin{array}{c}0.128 \\
(0.573)\end{array}$ & $\begin{array}{c}-1.142^{*} \\
(0.597)\end{array}$ \\
\hline$\%$ Population aged $<15$ & & $\begin{array}{c}1.021^{\star \star \star} \\
(0.184)\end{array}$ & & $\begin{array}{c}0.341^{\star * *} \\
(0.093)\end{array}$ \\
\hline Ifliteracy rate & & $\begin{array}{c}-0.452^{k \hbar \hbar} \\
(0.083)\end{array}$ & & $\begin{array}{c}-0.145^{* *} \\
(0.042)\end{array}$ \\
\hline Between R-squared & 0.34 & 0.90 & 0.71 & 0.91 \\
\hline Countries & 16 & 13 & 16 & 13 \\
\hline
\end{tabular}


Appendix Table 1

Episodes of Change in Polity IV Index of Democracy

\begin{tabular}{|c|c|c|c|c|}
\hline Country & Year & $\begin{array}{r}\text { Change in } \\
\text { Democracy } \\
\text { Index }\end{array}$ & $\begin{array}{r}\text { Resulting } \\
\text { Democracy } \\
\text { Index } \\
\end{array}$ & $\begin{array}{r}\text { Change in social } \\
\text { sector spending } \\
(\% \text { GDP) }\end{array}$ \\
\hline Gambia & 1994 & -8 & 0 & 1.29 \\
\hline Niger & 1996 & -8 & 0 & -1.54 \\
\hline Zambia & 1996 & -3 & 3 & 0.17 \\
\hline Kyrgyz Republic & 1996 & -2 & 4 & -1.59 \\
\hline Argentina & 1989 & -1 & 7 & -0.91 \\
\hline Dominican Republic & 1994 & -1 & 5 & 0.41 \\
\hline Madagascar & 1997 & -1 & 8 & 0.12 \\
\hline Mali & 1997 & -1 & 6 & 0.43 \\
\hline Malaysia & 1995 & -1 & 4 & -0.24 \\
\hline Turkey & 1993 & -1 & 8 & -0.26 \\
\hline Brazil & 1988 & 1 & 8 & 0.92 \\
\hline Chad & 1996 & 1 & 1 & 0.16 \\
\hline Egypt & 1990 & 1 & 1 & -0.51 \\
\hline El Salvador & 1991 & 1 & 7 & -1.03 \\
\hline Georgia & 1995 & 1 & 6 & 1.13 \\
\hline Guinea & 1995 & 1 & 1 & -0.40 \\
\hline Honduras & 1989 & 1 & 6 & 0.15 \\
\hline India & 1995 & 1 & 9 & -0.09 \\
\hline Jordan & 1989 & 1 & 1 & 0.66 \\
\hline Jordan & 1992 & 1 & 2 & 0.09 \\
\hline Mongolia & 1996 & 1 & 10 & 0.10 \\
\hline Panama & 1994 & $t$ & 9 & -0.08 \\
\hline Thailand & 1988 & 1 & 4 & -0.99 \\
\hline Tunisia & 1993 & 1 & 1 & 0.41 \\
\hline Ukraine & 1996 & 1 & 7 & -0.81 \\
\hline Uruguay & 1989 & 1 & 10 & 0.15 \\
\hline Kenya & 1997 & 2 & 2 & 0.13 \\
\hline Mexico & 1994 & 2 & 4 & 0.52 \\
\hline Mexico & 1997 & 2 & 6 & 0.47 \\
\hline Nicaragua & 1995 & 2 & 8 & 0.44 \\
\hline Turkey & 1989 & 2 & 9 & 7.05 \\
\hline Dominican Republic & 1996 & 3 & 8 & 0.26 \\
\hline Nepal & 1990 & 3 & 5 & -0.39 \\
\hline Paraguay & 1989 & 3 & 3 & 0.11 \\
\hline Romania & 1996 & 3 & 8 & -0.46 \\
\hline Guatemala & 1996 & 4 & 8 & 0.04 \\
\hline Mongolia & 1990 & 4 & 4 & 0.87 \\
\hline Paraguay & 1992 & 4 & 7 & 2.22 \\
\hline Mongolia & 1992 & 5 & 9 & -5.90 \\
\hline Bangladesh & 1991 & 6 & 6 & 0.37 \\
\hline Mozambique & 1994 & 6 & 6 & -1.02 \\
\hline Bulgaria & 1990 & 8 & 8 & 0.90 \\
\hline Lesotho & 1993 & 8 & 8 & 1.58 \\
\hline Panama & 1989 & 8 & 8 & -0.93 \\
\hline
\end{tabular}

Notes: Data are sorted by change in democracy index. Data refer only to those cases for which before and after the change the democracy index was stable for a two year period, to identify periods of "clean" changes in democracy index. The last column gives the change in the sum of education and health spending as \% of GDP for the two years before and after the change in democracy. 
Appendix Table 2

Sources and Summary Statistics for Control Variables

\begin{tabular}{|c|c|c|c|c|c|c|c|}
\hline Variable & Source & & Mean & Std. Dev. & Min & Max & Observations \\
\hline Log (real GDP per capita) & $\begin{array}{l}\text { Summers-Heston } \\
\text { PWT } 5.6\end{array}$ & $\begin{array}{r}\text { overall } \\
\text { between } \\
\text { within }\end{array}$ & 7.89 & $\begin{array}{l}1.07 \\
1.06 \\
0.13\end{array}$ & $\begin{array}{l}5.28 \\
5.74 \\
7.01\end{array}$ & $\begin{array}{r}10.03 \\
9.81 \\
8.73\end{array}$ & $\begin{array}{r}N=1816 \\
n=138 \\
\text { T-bar }=13.16\end{array}$ \\
\hline Log (total country population) & GDF and WD! & $\begin{array}{c}\text { overall } \\
\text { between } \\
\text { within }\end{array}$ & 15.43 & $\begin{array}{l}1.96 \\
1.99 \\
0.09\end{array}$ & $\begin{array}{l}10.62 \\
10.64 \\
15.00\end{array}$ & $\begin{array}{l}20.94 \\
20.86 \\
15.79\end{array}$ & $\begin{array}{r}N=2278 \\
n=164 \\
\text { T-bar }=13.89\end{array}$ \\
\hline $\begin{array}{l}\text { Log (total trade (imports + exports) } \\
\text { as \% of GDP) }\end{array}$ & GDF and WD! & $\begin{array}{l}\text { overall } \\
\text { between } \\
\text { within }\end{array}$ & 4.17 & $\begin{array}{l}0.60 \\
0.56 \\
0.21\end{array}$ & $\begin{array}{l}0.87 \\
1.64 \\
2.78\end{array}$ & $\begin{array}{l}5.47 \\
5.25 \\
5.11\end{array}$ & $\begin{array}{r}N=1915 \\
n=157 \\
\text { T-bar }=12.20\end{array}$ \\
\hline $\begin{array}{l}\text { Urban population, as } \% \text { of total } \\
\text { population }\end{array}$ & WDI & $\begin{array}{r}\text { overall } \\
\text { between } \\
\text { within }\end{array}$ & 49.72 & $\begin{array}{r}22.98 \\
22.88 \\
2.74\end{array}$ & $\begin{array}{r}4.40 \\
5.45 \\
27.82\end{array}$ & $\begin{array}{l}97.36 \\
96.65 \\
70.78\end{array}$ & $\begin{array}{r}N=2268 \\
n=162 \\
T=14\end{array}$ \\
\hline $\begin{array}{l}\text { Population aged } 0-14 \text {, as } \% \text { of total } \\
\text { population }\end{array}$ & WDI & $\begin{array}{r}\text { overall } \\
\text { between } \\
\text { within }\end{array}$ & 34.75 & $\begin{array}{r}10.13 \\
9.90 \\
1.35\end{array}$ & $\begin{array}{l}14.67 \\
16.03 \\
28.51\end{array}$ & $\begin{array}{l}51.52 \\
49.35 \\
39.60\end{array}$ & $\begin{array}{r}N=2177 \\
n=163 \\
\text { T-bar }=13.36\end{array}$ \\
\hline $\begin{array}{l}\text { Illiteracy rate, as } \% \text { of people aged } \\
15 \text { and above }\end{array}$ & WDI & $\begin{array}{r}\text { overall } \\
\text { between } \\
\text { within }\end{array}$ & 28.20 & $\begin{array}{r}23.11 \\
22.97 \\
3.25\end{array}$ & $\begin{array}{r}0.20 \\
0.20 \\
16.82\end{array}$ & $\begin{array}{l}90.40 \\
88.02 \\
40.12\end{array}$ & $\begin{array}{r}N=1624 \\
n=116 \\
T=14\end{array}$ \\
\hline Military expenditure, as \% of GDP & WDI & $\begin{array}{r}\text { overall } \\
\text { between } \\
\text { within }\end{array}$ & 3.59 & $\begin{array}{l}4.81 \\
3.53 \\
3.18\end{array}$ & $\begin{array}{r}0 \\
0 \\
-15.60\end{array}$ & $\begin{array}{r}101.90 \\
23.98 \\
81.50\end{array}$ & $\begin{array}{r}N=1576 \\
n=146 \\
\text { T-bar }=10.79\end{array}$ \\
\hline
\end{tabular}

Notes: "GDF" is Global Development Finance, and "WDI" is World Development Indicators, both World Bank data publications. PWT is Penn World Tables. The first three variables are obtained electronically from the Global Development Network Growth Database (William Easterly and Mirvat Sewadeh) at the World Bank's web site. Missing data for real GDP per capita are calculated from 1985 GDP per capita and GDP per capita growth rates from GDF and WDI. "Between" refers to county averages and "within" refers to devations from country averages plus overall mean. "T-bar" is average observations per country. 